\title{
COMMENT
}

\section{THE SECURITIES ACT OF 1933, THE MODERN CORPORATION AND THE THEORY OF FREE ENTERPRISE}

\section{INTRODUCTION}

$N$

EW DEAL legislation and administration in the field of corporate finance and management are too often discussed on the basis of a general predisposition toward or against "regulation." While it has often been recognized that the modern corporation is a central phenomenon in our economy, ${ }^{x}$ there have seldom been attempts to utilize economic theory, or an analysis of the operation of a competitive, free enterprise system of organization, as an aid in understanding and evaluating various kinds of regulatory legislation. Such an analysis is here attempted with respect to some aspects of the administration of the Securities Act of $1933^{2}$ by the Securities and Exchange Commission. ${ }^{3}$

× See Berle and Means, The Modern Corporation and Private Property (1934).

${ }^{2} 48$ Stat. 74 (1933), 5 U.S.C.A. $\$ 77$ a (Supp. 1938 ).

3 To make such an analysis places upon one the obligation of warning the reader of the assumptions upon which the analysis rests.

It is assumed that the system of sanctions which the Securities Act imposes effectively insures that persons responsible for the distribution of new securities issues, acting in their self-interest, will make that disclosure which the Act contemplates. It is the task of another study, therefore, to determine the policy behind loopholes in the liability provisions.

Even if the assumption be made that the liability provisions are effective to force security issuers to comply with the substantive provisions of the Act, there is no great certainty that any particular rule promulgated by the commission in aid of the general language of the substantive provisions represents "the law" with respect to what security issuers must disclose or the manner in which they must make disclosure. Except in $\S{ }_{7}$ (with whose administration this note is not concerned), the Act only penalizes non-disclosure or omissions of material facts $(\$ \S 5,8$, IO, II, I2, 24). Although the facts which those drafting the Act regarded as "material" to the investor are indicated by the contents of Schedules A and B, it is hardly thinkable that courts would hold all of the data required by those schedules to be material. The commission only lays down the broad test that a "material fact" is "a fact" which would tend "to deter the average prudent investor from purchasing the securities in question." Matter of Howard et al., I S.E.C. 6, 8, i8 F.T.C. 626, 629 (I934). Even if one overlooks the diffculty of differentiating between answers responsive to items in the forms and answers not so responsive ( $f f$. Matter of Oklahoma-Texas Trust, Sec. Act Rel. I563 at II-12 (I937), aff'd roo F.(2d) 888 (C.C.A. roth r939) with Matter of Metropolitan Personal Loan Co., Sec. Act Rel. 1594 at 3, n.3 (1937)), in construing too few items of the forms promulgated by the commission pursuant to statutory authorization ( $(\mathrm{Ig}(\mathrm{a}))$ has the commission held that failure to make an answer to an item of a form prima facie constitutes a deficiency (Matter of Nat'l Boston Montana Mines Corp., 2 S.E.C. 226, 262 (I937); Matter of Bering Straits Tin Mines 
A basic problem of any social organization is ascertainment of what is the most socially desirable aggregate of material goods and determination of the mechanism by which this corpus of wealth may be produced and distributed in a manner most in accord with the general welfare. In its theoretical formulation of this problem recent Western civilization has been greatly influenced by economic theory in the tradition of Adam Smith's Wealth of Nations. Proponents of such theory argue that the mainspring of the action of men in society is economic self-interest or "the natural effort of every individual to better his own condition"; 4 and that, if each person in a society is placed in a position which will enable him freely to pursue his economic self-interest, the result is to "place every productive resource in that position in the productive system where it can make the greatest possible addition to the social dividend as measured in price terms" and "to reward every participant in production by giving it the increase in the social dividend which its co-operation makes possible. ...."."s

It is frequently suggested, of course, that actual conditions are widely

Inc., Sec. Act Rel. I498 at 7 (I937); Matter of Canusa Gold Mines Ltd., Sec. Act Rel. I507 at Io, n.* (I937); Matter of Old Diamond Gold Mines Ltd., Sec. Act Rel. I576 at I-2 (1937); Matter of Oklahoma-Texas Trust, Sec. Act Rel. $x_{5} 6_{3}$ (I937), aff'd Ioo F.(2d) 888 (C.C.A. roth 1939)), or that failure to present data in the manner called for by the commission's instructions constitutes a deficiency (Matter of Bering Straits Tin Mines Inc., Sec. Act Rel. I498 at 7 (I937); Matter of Ypres Cadillac Mines Ltd., Sec. Act Rel. I652 at ro-II (1938); Matter of Oklahoma Hotel Building Co., Sec. Act Rel. 1900 (x939)), or that failure to include data not responsive to an item of a form does not constitute a deficiency (Matter of Metropolitan Personal Loan Co., Sec. Act Rel. I594 at 3, n. 3 (1937); Matter of Queensboro Gold Mines Itd., Sec. Act Rel. I6I7 at 4 (I937); Matter of Kinmer Airplane and Motor Corp. Itd., Sec. Act Rel. I644 (1937); Matter of Ypres Cadillac Mines Ltd., Sec. Act Rel. I652 at 8-9 (x938); Matter of South Umpqua Mining Co., Sec. Act Rel. I694 at 8 (1938); Matter of United Combustion Corp., Sec. Act Rel. I828 at I, n. I (r938); Matter of Oklahoma Fotel Building Co., Sec. Act Rel. I900 (I939); contra: cases cited in notes I33 and I79 infra.) For there to be any definite assurance that the facts called for by the forms are regarded by the commission as either indispensable or sufficient for prudent investment. In any event, either courts or juries will have ultimately to decide what constitutes materiality of misstatement or omission. In view of the fact, however, that in over five years of litigation only one stoporder proceeding has been reviewed, materiality is as a practical matter an issue for the commission. To make any progress in analysis of the commission's activities, it must be assumed that the commission's rules have the force of law, and that the ambit of disclosure which the commission deems essential may be found by analysis of its rules and instructions.

No attempt is here made to offer comprehensive citation of secondary sources. Any effort to present more than citations to authority of official or semi-official status would be an inadequate duplication of the bibliography recently promulgated by the commission (Bibliography: Securities and Exchange Commission Library (r937)).

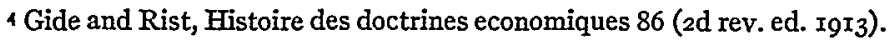

5 Knight, Ethics of Competition 48 (1935). 
divergent from those visualized by such analysis. But it has also been said that the economic policy formulated by the classical analysis has never failed because it has never been tried, ${ }^{6}$ and that the "idea of a purely individualistic order is a logical device, necessary to separate for study tendencies of individualism from those of socialism." 7 The reason for these and similar statements is that in practice the "restraints" upon the ideal working of the scheme of free enterprise, the removal of which classical economists agree is a proper province of government, ${ }^{8}$ are fully as important as the forces actually operating in accord with the theory of free enterprise.

One such restraint arises from the failure of society to approximate a condition of perfect mobility of buyers and sellers. The concept of mobility implies perfect knowledge on the part of any buyer or seller of goods or productive services of facts which would render one course of action of greater economic benefit to him than any other, and perfect freedom on the part of any buyer or seller to adopt immediately that most favorable course of action. Imperfect mobility tends to delay or prevent the flow of capital into that industry where it will bring the greatest return, and to delay or prevent the transfer of capital from less efficient to more efficient business units within an industry. To the extent that these consequences result, the economic system fails to attain those ends which classical economic theory deems desirable.

Immobility due to lack of knowledge of persons supplying capital to business enterprises may result from the failure of such persons to be cognizant of all knowable facts bearing upon the advisability of investment, or from their failure to be aware of the uncertainties of business which they assume by entrusting funds to business enterprise. If one is to invest intelligently, he must differentiate between avoidable uncertainty, any business risk which is within the power of men to eliminate, and unavoidable uncertainty, any business hazard which man is powerless to efface.

The principal aim of the Securities Act is to require that offerors of new securities issues make available to prospective purchasers knowable facts bearing upon the advisability of purchasing the securities offered. In addition, the act requires that the issuers give full information regarding unavoidable and avoidable risk to be borne by the purchasers of the securities offered. The inferior quality of information which was available

${ }^{6}$ Soule, The Coming American Revolution 138 (1934).

7 Knight, op. cit. supra note 5 , at 47.

${ }^{8}$ Gide and Rist, op. cit. supra note 4 , at 96 . 
to prospective investors prior to the Securities Act, ${ }^{9}$ and the disastrous losses which investors suffered in the depression years, ${ }^{\mathrm{I0}}$ dictated the need of federal legislation to accomplish the aim of adequate disclosure.

\section{THE COMMISSION'S VIEW OF THE SCOPE OF ITS POWER}

If the Securities Act represents an effort to promote a closer approximation to a free market for investment capital, it would be expected to remove obstacles to intelligent decisions by investors not only by requiring disclosure of material facts and penalizing misstatements but also by prohibiting a presentation of accurate information in a form likely to mislead. That the commission views its quasi-judicial power ${ }^{\mathrm{Ix}}$ under the Act as a power to give the Act this liberal construction is revealed by its opinions on a number of questions.

Perhaps the closest of such questions is whether or not a registrant may include in the answer to an item of the registration statement or in the prospectus information which, if it has any effect upon the investor, has the effect of misleading him, provided that the registrant includes in close juxtaposition information which should enable the average prudent investor to give the misinforming data its true significance. On this issue the opinions promulgated by the commission are not consistent. On the one hand, there are strong dicta in Matter of Herman Hanson Oil Syndicate $^{\mathrm{T} 2}$ and similar cases ${ }^{\mathrm{T} 3}$ which imply that the province of the commission is merely to require that all material facts bearing upon the significance

9 See the classic discussion in Ripley, Main Street and Wall Street 208-228 (I929).

so "During the post-war decade some 50 billions of new securities were floated in the United States. Fully half or $\$ 25,000,000,000$ worth of securities floated during this period have been proved to be worthless." H.R. Rep. 85 at 2 (73d Cong. Ist Sess. 1933).

"r See Securities Act of $1933, \S 8$.

${ }^{\mathrm{I}}$ Sec. Act Rel. I555 at 3 (I937) (valuation by divining rod materially misleading unless the registrant reveals clearly and without camouflage that the divining instrument is not considered by any recognized authority to be of any use whatsoever in locating oil or other minerals). Cf. Matter of La Luz Mining Corp., I S.E.C. 2x7, 218-22 (r935).

${ }_{3}$ An outdated mining report may not be included in the registration statement without also including therein corrections of the report which were necessary in the light of facts which were known or should have been known between the date of the mining report and the effective date of the registration statement (Matter of Franco Mining Corp., I S.E.C. 285, 290 (x936); Matter of Emporia Gold Mines Inc., 2 S.E.C. 209, 220 (I937); Matter of Nat'I Boston Montana Mines Corp., 2 S.E.C. 226, 26I (1937). Cf. Matter of Mining and Development Corp., I S.E.C. 786, 799-804 (1936)). See also Matter of Bering Straits Tin Mines Inc., Sec. Act Rel. I498 at 8 (I937) (". . . unless clearly informed to the contrary investors are entitled to believe that such a figure, $[\$ 74,977]$ on the balance sheet represents cost or 'value' arrived at by the use of accepted methods of valuation and is not an arbitrary figure."); Matter of American Kid Co., Sec. Act Rel. 1678 ( 1938 ) (an estimate of future profit given in a prospectus does not meet the requirements of full and adequate disclosure imposed by the Act unless the doubtful character of its premise is revealed). But more recently, see Accounting Rel. 4 (I938). 
of the registrant's assertion be presented in close juxtaposition to the assertion.

In Matter of West Park Apartments ${ }^{\mathrm{x}}{ }^{4}$ this position has attained the dignity of a holding. The holding, however, is entitled to but slight weight since the misrepresentation involved was very small, was corrected elsewhere in the registration statement, and was found to be without the capacity to mislead. A different view, however, is illustrated in the cases holding an appraisal deficient for failure to follow scientific methods. ${ }^{\text {I5 }}$ The whole trend of the latter cases is toward the view that the commission is both to pass upon the truth or falsity of items in the registration statement and admit into the statement and prospectus only such assertions as convey a true impression of the registrant and of its business condition. The commission has even held, for example, that an opinion stated by an expert ${ }^{\mathrm{T} 6}$ is prima facie deficient if the supposed expert had no basis for his opinion. ${ }^{17}$ These cases are arguably reconcilable with the Hanson and West Park Apartment cases on the ground that it does not appear in any of them that the baseless character of the opinion is fully disclosed in close juxtaposition to the baseless statement. This argument, however, can hardly be made with respect to the rule that an indication in a footnote to a financial statement ${ }^{18}$ or in the accountant's certificate that an item in the financial statement was not arrived at by use of accepted accounting principles will not prevent the misleading item from being deficient. ${ }^{x}$

It would seem that the latter of the two positions which we have dis${ }^{34} \mathrm{Sec}$. Act Rel. I8Ir at 9 (1938). is Note 77 infra.

${ }^{16}$ For the commission's concept of the expert see Matter of Gilpin Eureka Consolidated Mines, I S.E.C. 752,757 ( 9936$)$.

${ }^{17}$ Matter of Emporia Gold Mines Inc., 2 S.E.C. 209, 219 (1937).

${ }^{18}$ The commission has consistently held that an erroneous item in a balance sheet cannot be corrected by a footnote to the balance sheet (Matter of Mining and Development Corp., I S.E.C. 786, 798 (I936); Matter of Yumuri Jute Mills, 2 S.E.C. 8I, 87 (r937); Matter of Queensboro Gold Mines Ltd., Sec. Act Rel. I6I 7 at 2 (I937)). This conclusion has been reached even when the item challenged is the title of an account which is not incorrect but which is merely ambiguous, the footnote being used to remove the ambiguity (Matter of Canusa Gold

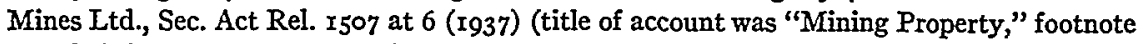
revealed that the property was held under lease and option). But a footnote is properly used to indicate contingencies on which statements in the balance sheet which are presently true will be untrue (Matter of Canusa Gold Mines, Ltd., Sec. Act Rel. I507 at 7 (1937). See Matter of Bankers Union Life Co., 2 S.E.C. $6_{3}, 68$ ( 1937 )); or to indicate that a transaction given effect on the balance sheet may be illegal under state law (Matter of Peterson Engine Co., Inc., Sec. Act Rel. 1627 at II-12 (I937)). Cf. Matter of South Umpqua Mining Co., Sec. Act Rel. I694 at 6 (1938).

x9 Accounting Rel. 4 (x938). This ruling assumes additional significance since the commission formerly held otherwise. See Healy, The Next Step in Accounting, I3 Accounting Rev. I, 4 (1938). 
cussed is the more reasonable. The words of the statute do not require the adoption of the former view; ;o and the economic policy of the Securities Act seems clearly opposed to its adoption; since a baseless opinion or a fortiori a flatly false statement, if of any influence upon the investor, must in most instances misinform him. In any event it has uniformly been ruled that, if a deficiency in the registration statement or prospectus is material, it may not be corrected by information in another part of the registration statement or prospectus ${ }^{25}$ in the absence of permissible cross-reference between the items. ${ }^{22}$

Other cases which more clearly suggest that the commission views its province to be the elimination of anything which may prevent the investor from acting in accord with his economic self interest are those in which the commission holds that a statement may be deficient, though literally true, because the investor is apt to draw incorrect inferences. ${ }^{23}$ One group of cases establishing this principle includes those cases in which the commission uniformly rules that incomplete presentation of a subject may be materially misleading because an investor who reads a statement on a given subject may naturally assume that all material facts with reference to that subject are presented in that statement. ${ }^{24}$ The commis-

${ }^{20} 48$ Stat. 87 (I933), I5 U.S.C.A. $\$ 77 \mathrm{~W}$ (I938) says nothing to the contrary.

${ }_{25}$ A misrepresentation or under-estimate of operating cost in a mining report is not cured by use of the correct value in valuing assets (Matter of Sunset Gold Fields Inc., 2 S.E.C. 329 , 335 (I937)). A statement in a mining report that a mine contains a certain number of tons of "proven" ore is deficient when elsewhere in the registration statement facts are revealed showing that the engineer could not have assigned any tonnage to proven ore following the method of appraisal which he followed (Matter of Emporia Gold Mines Inc., 2 S.E.C. 209, 216 (I937)). A statement in large type in a prospectus cannot be corrected by a statement in small-type even if the latter is made in reasonably close proximity to the former (Matter of Bankers Union Life Co., 2 S.E.C. 63, 66 (I937); Matter of National Educators Mutual Ass'n, I S.E.C. 208, 2 rr (r935)).

${ }^{22}$ Matter of T.I.S. Management Corp. Sec. Act Rel. 1689 at 2-6 (x938). See Regulation C, article ${ }_{3} \mathrm{C}$, General Rules and Regulations, Sec. Act of 1933 at $47-49$ (1938).

${ }^{23}$ The source of this doctrine is Rex v. Kylsant, [r932] I K.B. 442. This case figured prominently in the minds of those drafting the Securities Act. See, for example, Hearings before the Committee on Interstate and Foreign Commerce on H.R. $43 \pm 4$ at II (73d Cong. Ist Sess. 1933).

${ }^{24}$ Matter of Livingston Mining Co., 2 S.E.C. I4I, I48 (I937) ("It is misleading merely to state the few facts about properties that are known, without making it clear that many facts are unknown, that the records are incomplete, and that part of what has been stated is mere guess and we so find"); Matter of Hanson Oil Syndicate, Sec. Act Rel. I555 (r937) (statement that a "big" oil well had been discovered in the vicinity of property belonging to the registrant held materially misleading for non-disclosure that the well had begun to produce $80 \%$ water and had to be cemented back); Matter of South Umpqua Mining Co., Sec. Act Rel. I694 (r938) (answer to item asking for sales of securities to the public within two years preceding filing of the registration statement held deficient for failure to include all sales); Matter of Unity Gold Corp., Sec. Act Rel. I776 at II (1938) (statement that application for registration 
sion's zeal to hold deficient possibly misleading assertions which are literally true extends not only to true though incomplete statements, but to ambiguous statements which are true in only one sense. Consequently, a bond may not be given a "dollar" value when it is in fact payable threequarters in cash and one-quarter in stock..$^{25}$ It has even been held, that if a registrant states at one point that a certain promoter is a mining engineer, it may not state elsewhere that the promoter has spent a certain period of time inspecting properties, since the investor may infer that the promoter was inspecting the properties as a mining engineer when actually he was inspecting them with a view to their purchase. ${ }^{26}$ The unexplained use of a word in a sense other than one generally accepted, ${ }^{27}$ or the use of a word in two senses without making graphically clear the shift in meaning, ${ }^{28}$ also constitutes a material deficiency.

Other general principles developed by the Securities and Exchange Commission tend to reinforce the basic position that the commission views its power as one to eliminate anything with any appreciable tendency to prevent the investor from being fully informed. For example, if the registrant constantly repeats and stresses a favorable but only slightly material fact, ${ }^{29}$ an immaterial fact,,$^{30}$ or a fact whose relevance the regis-

of securities with a state regulatory body was "withdrawn" or "withdrawn without prejudice" held materially misleading because the registrant omitted to state that it was its understanding that if not withdrawn, the application would be denied). See also Matter of Howard et al., I S.E.C. 6, ro, r8 F.T.C. 626, 632 (1934); Matter of Commonwealth Bond Corp., r S.E.C. 13, 23, I8 F.T.C. 635,647 (1934); Matter of Avocalon Extension Syndicate Ltd., I S.E.C. 657,659 (I936). This rule may be applied even though the deficiency appears on the face of the answer to the item. (Matter of Unity Gold Corp., Sec. Act Rel. I776 at ro, n. I9 (r938) (statement that option contract was signed by 14 optionees was deficient in giving neither the names of optionees nor the number of shares optioned)).

${ }_{25}$ Matter of Bankers Union Life Co., 2 S.E.C. 63,66 (1937).

${ }^{26}$ Matter of Platoro Gold Mines Inc., Sec. Act Rel. I807 at 4 (1938).

${ }_{27}$ Matter of Nat'l Educators Mutual Ass'n, I S.E.C. 208, 213 (I935); Matter of Oil Ridge Oil and Refining Co., I S.E.C. 225, 228 (1935); Matter of American Terminals and Transit Co., I S.E.C. 70r, 724 (1936); Matter of Livingston Mining Co., 2 S.E.C. I4I, I50 (1937); Matter of Rickard Ramore Gold Mines, Itd., 2 S.E.C. 377, 388 (I937); Matter of Income Estates of America, 2 S.E.C. 434, 439 (I937); Matter of West Park Apts. Corp., Sec. Act Rel. $\mathrm{r} 8 \mathrm{II}$ at 6 (r938).

${ }^{28}$ Matter of Underwriters Group Inc., Sec. Act Rel. 1653 at ${ }_{4}$ (1938).

${ }_{29}$ Matter of Income Estates of America, 2 S.E.C. 434, 443 (1937) (registrant repeatedly reiterated in the prospectus the name, functions, and long and successful history of a trustee; this was held materially deficient when the trustee was without discretion in connection with the investment of the funds in trust and when the registrant was a new and completely unknown corporation).

${ }^{30}$ See Matter of Emporia Gold Mines Inc., 2 S.E.C. 209,220 (1937) (inclusion in prospectus of true and optimistic account of mining properties located not less than rooo miles from those of the registrant). 
trant cannot demonstrate $;^{3 \mathrm{I}}$ if the registrant separates in the prospectus facts which would give a less favorable position if placed together $;^{32}$ or if the registrant presents complex facts in a complicated manner in a prospectus directed to the financially uninitiate; ${ }^{33}$ the commission may apply the rule that although no assertion is untrue a registration statement or prospectus may be found materially deficient because the manner of presentation is deceptive. ${ }^{34}$ Complex presentation of facts in a prospectus is, in any event, discouraged by the rules as to summarization. ${ }^{35}$

Even with the fullest possible disclosure and the most ample protection against misleading suggestion, ${ }^{36}$ a limbo of uncertainty will necessarily remain as to the prospects of the enterprise. Here it is important that the investor be made conscious of the risks involved in the enterprise itself and of the portion of the risk which he will bear. Such caution is important not only for the purchaser of common stock but also for the purchaser of bonds. Seldom will specific security or the investment by stockholders furnish complete protection for bondholders; in most cases, in view of the limited liability of stockholders, bondholders share the ultimate risk of the enterprise. Unless they understand the extent to which they are thus entrepreneurs, they are not in position to weigh the return offered them

${ }^{3 x}$ Matter of Gilpin Eureka Consolidated Mines Inc., I S.E.C. 752, 76I (I936). Cf. Matter of Nat'l Invested Savings Corp., I S.E.C. 825,829 (I936).

${ }^{32}$ Matter of Austin Silver Mining Co., Sec. Act Rel. r774 at 6 (I938).

${ }^{3}$ Matter of Nat'l Educators Mutual Ass'n, I S.E.C. 208, 2x5 (I935); Matter of Income Estates of America Inc., 2 S.E.C. 434, 445 (I937).

34 It follows $a$ fortiori that a deficiency which is immaterial may result in a materially deficient registration statement or prospectus in the event that there are one or more other deficiencies in the document, any of which taken alone would be immaterial. (Matter of Nat'l Educators Mutual Ass'n, I S.E.C. 208, 215 (I935); Matter of Mutual Industrial Bankers Inc., I S.E.C. 268 (1936); Matter of Income Estates of America, 2 S.E.C. 434, 442 (I937); Matter of Austin Silver Mining Co., Sec. Act Rel. I774 at 6 (x938). Cf. Matter of Metropoli$\tan$ Personal Loan Co., Sec. Act Rel. 1594 at 7 (1937)).

${ }_{35}$ Matter of Underwriters Group Inc.; Sec. Act Rel. I653 at I2 (I938). Cf. Opinions of the Director of the Division of Forms and Regulations, Sec. Act Rel. 874 (1936), I503 (1937), I580 (1937); Rule 82I, General Rules and Regulations, Securities Act of I933 at 47 (1938).

${ }^{36}$ The cases which have been cited in this section all tend to establish the proposition that in response to any item in a registration form the registrant must avoid placing any statement in such form that it will tend to mislead. If the registrant volunteers information not called for by the forms he will be held to this same standard. (Cf. Matter of Treasure Hill Extension Mines Co., Inc., 2 S.E.C. I34, $x_{3} 8$ (I937); Matter of Emporia Gold Mines Inc., 2 S.E.C. 209, 216 (I937); Matter of Paper Sales Co. of Detroit, Sec. Act Rel. r556 at 6 (I937) as amended by Sec. Act Rel. I665 (1938); Matter of Platoro Gold Mines Inc., Sec. Act Rel. r807 at 7 (r938); a stop order may issue if the information volunteered does not meet this standard ( $C f$. Matter of Unity Gold Corp., I S.E.C. 25, 28, I8 F.T.C. 649, 653 (1934); Matter of Commonwealth Bond Corporation, I S.E.C. I3, I8, I8 F.T.C. 635,643 (I934); Matter of Emporia Gold Mines Inc., 2 S.E.C. 209, 2 I6 (I937)). 
against this risk of loss. To the extent that purchasers of securities assume risks inadvisedly, the benefits of a competitive capital market in directing the allocation of resources into most productive channels will fail of achievement. The commission, therefore, quite properly takes the position that "the investor is entitled to know not only the facts which are established; it is frequently more vital for him to be cautioned that there are areas of information about which there is considerable doubt." ${ }_{37}$

To digest the decisions which the commission has rendered requiring facts reasonably knowable ${ }^{38}$ with respect to the business enterprise to be revealed, would be to deal with the commission's least difficult and least interesting opinions. ${ }^{39}$ The remainder of this paper, therefore, is a discussion of those uncertainties inherent in business and the modes of description of the business enterprise which the commission has adopted as best calculated to bring to light such uncertainties.

\section{DISCLOSURE OF UNAVOIDABLE UNCERTAINTY VALUATION OF FIXED ASSETS}

The unavoidable uncertainties of business are particularly striking in the case of enterprises in which investment in fixed assets bulks large, for fixed plant and equipment is in a large measure irrevocably committed to the enterprise. Since investment in any fixed asset is usually to be recovered only through the sale of products over the period of the useful life of the asset, an accurate valuation of the asset would represent its future contribution to product value discounted to present worth. No business, however, can make such a valuation because of uncertainty as to the future demand for its product..$^{\circ}$ Consequently, any balance sheet valua-

${ }^{37}$ Matter of Livingston Mining Co., 2 S.E.C. $14 \mathrm{I}, 148$ (1937), followed and approved in Matter of Platoro Gold Mines Inc., Sec. Act Rel. 1807 at 5, n. 14 (1938). See also Matter of West Park Apts. Corp., Sec. Act Rel. I8rr at 5 (1938).

${ }^{8}$ Except in answering items which only call for information known to the registrant, the registrant must furnish answers embodying all data which might be known at the effective date of the registration statement and which was reasonably knowable to the registrant at that time. Matter of Howard et al., I S.E.C. 6, Io, x8 F.T.C. 626, 632 (x934); Matter of Unity Gold Corp., I S.E.C. 25, 29, I8 F.T.C. 649, 653 (I934); Rule 502, General Rules and Regulations, Sec. Act of 1933 at $3^{6}$ (I938). That this rule is not appreciably different than the common law test of negligence appears from those numerous cases which hold that good faith is immaterial on the issue of whether or not a deficiency is present. The law of a jurisdiction in which the registrant has mining property should reasonably be known to the registrant. Matter of Oklahoma-Texas Trust, Sec. Act Rel. $1_{56}$ at I4 (I937), aff'd I0 F. (2d) 888 (C.C.A. Ioth 1939).

${ }^{39}$ See, however, note 77 infra.

${ }_{40}$ "The uncertainties which persist as causes of profit are those which are uninsurable because there is no objective measure of the probability of gain or loss. This is true especially 
tion of a fixed asset must be unsatisfactory since it conceals the risk that the asset will not be realized at any foreseeable amount.

\section{A. STANDARDIZATION OF CONVENTIONAL MODE OF VALUATION}

The most conservative effort of the Securities and Exchange Commission in connection with effecting a proper valuation of fixed assets has been an effort at standardization of the definition of certain concepts used by accountants to value fixed assets, the purpose of such standardization being to give fixed asset accounts, in financial statements of different enterprises in the same and different industries, that degree of comparability in the absence of which the prospects of enterprises competing for free capital cannot intelligently be evaluated. ${ }^{4 x}$

of the prediction of demand. It not only cannot be foreseen accurately, but there is no basis for saying that the probability of its being of one sort rather than another is of a certain value. Situations in regard to which business judgment must be exercised do not repeat themselves with sufficient conformity to type to make possible a computation of probability." Knight, Distribution: The Pricing of Productive Services Individually, Syllabus for the University of Chicago Second Year Course in the Study of Contemporary Society 224, 249 (I934).

${ }_{41}$ The commission has the power to prescribe uniform systems of accounts, uniform modes of valuation, and uniform forms of financial statements. 48 Stat. 908 (1934), I5 U.S.C.A. $\S 775$ (Supp. 1938). The textual discussion is concerned only with the commission's use of this power to standardize the modes of valuing fixed assets and income. See pp.4Ig-20 infra. Comparison of the forms of financial statement promulgated by the commission would doubtless reveal extensive standardization of the arrangement of financial statements and of the accounts included in financial statements. It would be found, for example, that unless trade practice is to the contrary no asset is a current asset unless it is realizable within a year from the date of the balance sheet in which the asset is set forth (Instruction Book for Form A-2 at 3I (I937)); and that the registrant may not denominate as paid-in surplus any amount in excess of the difference between the par or stated value of the registrant's stock and the consideration which the registrant has received for its stock (Instruction 22, Financial Statement Instruction Set No. I, Form E-I at 49 (r937); Instruction 22, Instructions Relative to Balance Sheets of the Issuer, Form A-I at 32 (I937) ). Any steps which the commission has taken to effect standardization of accounting principles to be employed by persons registering securities under the Securities and Securities Exchange Acts, are less far-reaching than the standardizations which the commission has effected pursuant to powers granted by the Public Utility Holding Company Act. See Uniform System of Accounts for Mutual Service Companies and Subsidiary Service Companies; Uniform System of Accounts for Public Utility Holding Companies. The commission recognizes that, since the ordinary investor does not have the time or skill necessary to translate the accounting language used by one issuer into the language used by another issuer (Werntz, Standardization of Accounting Principles I, 5, 9 (address released by the Securities and Exchange Commission 1938)) that it is as imperative to standardize the accounting principles followed by ordinary businesses as to standardize those followed by public utilities. But the commission also realized that extensive standardization must await the formulation of principles upon which good accountants can agree (ibid.). For efforts to formulate accounting principles see generally American Institute of Accountants, Audits of Corporate Reports (r934); Sanders, Hatfield, and Moore, A Statement of Accounting Principles (r938) and numerous articles in 9-13 Accounting Rev. (1934-38) and 58-66 J. of Accountancy (1934-38). A number of accounting principles upon which the commission has not yet taken 
I. ORIGINAL VALUE OF FIXED ASSETS

It has been customary to enter fixed assets on the books at "cost." The concept of "cost" is undoubtedly the most important valuation concept which the Securities and Exchange Commission's action has tended to standardize; yet the only purported definition of "cost" that has been found in the literature promulgated by the commission under the Securities Act involves a definition of the concept in terms of itself, ${ }^{42}$ and consequently is of no assistance in deriving the formula which the commission has really standardized. There have been many opinions, however, dealing with statements of "cost" in registration statements and a number of propositions have been established by the commission's decisions.

As of whatever time the cost of a fixed asset may properly be determined, the statement of cost may not exceed the exchange value ${ }^{43}$ in dollars of the assets exchanged for the fixed asset as such exchange value was or would have been fixed in a concurrent arms-length ${ }^{44}$ transaction. The leading authorities for this proposition are the cases in which the commission has held that a fixed asset may not be valued at the par value of stock exchanged therefor when at the date of such exchange the stock was worth less than par..$^{45}$ As adequate evidence of arms-length value of stock at the date on which it is exchanged for property, the commission accepts prices at which the stock was sold to the public a short time before the exchange, ${ }^{46}$ the market value of the stock at the date of the exchange, ${ }^{47}$ and the price at which the registrant will re-purchase its stock. In Matter of Yumuri Jute Mills ${ }^{4}$ the

a position will be incorporated in a regulation which will replace all financial statement instruction sets which the commission has promulgated pursuant to provisions of the Securities and Securities Exchange Acts. Werntz, op. cit. supra, at 6.

${ }_{42}^{2}$ Instruction as to Items $I_{2}$ (c) and $I_{3}$ (d). Instructions as to Particular Items of the Form, Instruction Book for Form A-O-I at 3 (1936).

43 By exchange value is meant market price.

44 An arms-length transaction means a transaction between strangers in a market. The transaction by definition is not a "forced sale"; it must be wholly voluntary on both sides. Exhibit K, Instruction Book for Form A-O-I at $\mathrm{I}_{4}$ (1936).

45 Matter of Unity Gold Corp., I S.E.C. 25, 33, I8 F.T.C. 649, 658 (I934); Matter of Yumuri Jute Mills, 2 S.E.C. 8I, 85 (r937); Matter of Nat'l Boston Montana Mines, 2 S.E.C. 226, 25I (1937); Matter of Canusa Gold Mines Ltd. Sec. Act Rel. I507 at 7 (I937); Matter of Virginia City Gold Mining Co., Sec. Act Rel. I6I5 at 3 (1937); Matter of Queensboro Gold Mines Ltd., Sec. Act Rel. I6I7 (r937).

${ }^{4}$ Matter of Unity Gold Corp. I S.E.C. 25,33 , I8 F.T.C. 649,658 (1934); Matter of Nat'l Boston Montana Mines Corp., 2 S.E.C. 226, 25 I (1937); Matter of Canusa Gold Mines Ltd., Sec. Act Rel. I507 at 7 (1937); Matter of Queensboro Gold Mines Ltd., Sec. Act Rel. I6I7 (1937).

47 Matter of Virginia City Gold Mining Co., Sec. Act Rel. I6 I5 at 3 (I937).

$4^{8} 2$ S.E.C. $8 \mathrm{r}, 84$ ( 1937 ). 
registrant put a balance sheet value on fixed assets determined by the stated value of no par common shares exchanged therefor. The registrant had an option to repurchase most of such shares at one-fifth their stated value but contended that this option would be exercised only if the registrant were forced to offer common stock to underwriters at one-fifth its stated value in order to induce them to underwrite an issue of registrant's preferred stock which was also being registered. The commission held that, since the registrant had for purposes of re-purchase valued its no par common stock at less than stated value the balance sheet item was misleading. It is to be doubted that the result would have been the same had the registrant offered proof that the market value of its stock was as great as that stated.

Even when the market value of a share of registrant's stock is as great as its par or stated value, the principle suggested finds application when, concurrently with the exchange of the fixed asset for a certain number of shares in the registrant, the seller of the fixed asset donates shares back to the issuer. ${ }^{49}$ In such circumstances the proper accounting entries have uniformly been held to be a debit to the fixed asset of an amount equal to the market value of the excess of shares exchanged over shares donated and an off-setting credit to capital stock.

As of whatever time the cost of a fixed asset may properly be determined, the statement of cost should not exceed the exchange value in dollars of the fixed asset as such exchange value was or would have been fixed in an approximately concurrent arms-length transaction.

In Matter of Continental Distillers $\&$ Importers Corp..$^{\circ}$ the facts were as follows: In October, I933, S, apparently in an arms-length transaction, paid $\$ 5,000.00$ for certain land, building and equipment. On the same day $S$ resold this property to a promoter of the registrant for $\$ 25,000.00$ or $\$ 35,000.00$. Four days later the promoter, who controlled the registrant, sold the property to the registrant, receiving payment in stock, the par value of which was $\$ 75,000.00$. In holding that it constituted a deficiency to value the property on the registrant's balance sheet at $\$ 75,000.00$, the commission remarked that "in view of the two almost concurrent sales of the property for $\$ 5,000.00$ and $\$ 35,000.00$ (or $\$ 25,000.00$ ), it appears that a large part of the consideration should be considered payment to pro-

${ }^{49}$ Matter of Unity Gold Corp., I S.E.C. 25, 30, I8 F.T.C. 649, 655 (I934); Matter of Bering Straits Tin Mines Inc., Sec. Act Rel. I498 at 8 (1937); Matter of Virginia City Gold Mining Co., Sec. Act Rel. $x_{65}$ at 3 (1937). Some accounting authorities sanctioned the alternative procedure of setting up the fixed asset at the full par value of stock exchanged therefor with the concurrent donation being set up as a treasury stock account. See citations in Matter of Unity Gold Corp., I S.E.C. 25, 3I, I8 F.T.C. 649, 656 (r934).

so I S.E.C. 54, 64, 78 (1935). Cf. discussion pp. 402-4 supra. 
moters and not cost of property..$^{5 x}$ The very least that was necessary to avoid a misleading effect in this respect was to state in connection with the property item on the balance sheet, that cost was determined in a sale in which the vendor.... was in control of the vendee. .... This fact is stated neither on the face of the balance sheet nor in the accountant's certificate."

The rule of the Continental Distillers case is not free from ambiguity. Registrants, however, would be well-advised to interpret the rule as a prohibition of any assertion that a fixed asset cost more than it would have cost in an arms-length transaction, since there is authority ${ }^{52}$ indicating that the result would have been the same had the distilling company included a qualifying statement in the balance sheet or in the accountant's certificate.

If, at the time that the registrant purchased a fixed asset, the arms-length exchange value of the assets exchanged by the corporation for the fixed asset was less than the arms-length exchange value of the fixed asset, the registrant may not enter the asset at more than the arms-length value of the assets so exchanged. While there is no direct holding to this effect, if, as has been held, ${ }^{53}$ it is improper accounting practice for a registrant corporation without an established record of earnings to write-up a fixed asset on the basis of reproduction cost new when the asset had previously been valued on the registrant's balance sheet at historical cost, it must be equally improper for such a registrant to make the same write-up when it had never entered the asset on the balance sheet at historical cost.

Accounts urge, ${ }^{54}$ as reasons for write-up of fixed assets to reproduction cost new, that failure to effect such write-up will result in underestimation of the fund necessary to replace fixed assets and overstatement of earnings from operations because depreciation would be figured upon too low a basis.

The commission apparently feels that it is neither as important for a concern to avoid such overstatement of its earnings nor to avoid understating the funds necessary for replacement of fixed assets, as it is that the investor be not lulled into a feeling, induced by write-up of the fixed as-

${ }^{5 x}$ It is improper accounting practice to include compensation to promoters for services as cost of property, Matter of Unity Gold Corp., r S.E.C. 25, 30, I8 F.T.C. 649,654 (I934) and numerous succeeding cases.

52 Accounting Rel. 4 (1938).

53 Matter of Unity Gold Corp., Sec. Act Rel. 1776 (1938); Accounting Rel. 8 (I938). Cf. Atlantic, Birmingham and Coast Ry. v. United States, 296 U.S. 33, 39 (r935); Matter of Arkansas-Missouri Power Corp., 2 S.E.C. 4I3 (1937). For citations to cases holding that reproduction cost new is in any event only one factor to take into consideration in valuation of fixed assets, see Matter of Unity Gold Corp., Sec. Act Rel. I776 at I4, n. 27 (1938).

54 Graham and Katz, Accounting in Law Practice § 127 (Ist ed. 1932). 
sets, that the concern has a favorable future. ${ }^{55}$ While the above principle is derived from cases testing the adequacy of registration statements of untried concerns, there is no indication that the same principle would not be applied in ascertaining the value at cost of the assets of a "going concern." 56

The cost which the commission requires to be stated is the "cost to the enterprise of which the registrant is the whole or any part" and not the "cost to the registrant." 57

2. CORRECTION OF ORIGINAL VALUE TO ACCORD WITH SUBSEQUENT VALUE

a) As discussed in the preceding section, the commission requires that the registrant shows as the "cost" of a fixed asset either what was paid for it or what it was worth, whichever amount was less at the time of purchase of the asset. As time passes, and the useful life of the fixed asset grows shorter, this original value ceases to bear any relation to actual value. On the other hand, there still is no basis for determining with exactitude the contribution of the fixed asset to the proceeds of future products and the period of such contribution. In view of the certainty that subsequent value is not equal to original value, and in view of the uncertainty as to subsequent value, the commission has held on the one hand that failure to depreciate or amortize an asset over its known or estimated life constitutes a deficiency, ${ }^{58}$ at least, if the registrant does not make a statement contradicting the assumption that it followed standard accounting principles.59 On the other hand, the commission appears to require no one mode of setting up of a reserve for depletion or depreciation to effect amortization of plant, buildings, and equipment, ${ }^{60}$ intangible assets ${ }^{6 \mathrm{x}}$

5s Commissioner Fealy has said in this connection: "Accounting to me means the making of a historical record of financial events. Valuation is a very different matter. I do not mean that there are no circumstances under which unrealized losses or gains should be recognized on books of account. I do believe that unrealized gains should not be entered into books of account until the probability or certainty of the permanence of the gain can be well established. I believe that good accounting should observe this principle." Healy, op. cit. supra note I9, at 8.

${ }_{56}$ "Stop order opinions usually involve newly organized, and often wholly speculative companies. Yet the principles therein applied are equally applicable to established companies if similar facts are involved." Werntz, op. cit. supra note $4 \mathrm{I}$ at 7 .

57 Pp. 434-45 infra.

${ }^{88}$ Accounting Rel. 7 at 4 (1938). Cf. Matter of Golden Conqueror Mines Inc., Sec. Act Rel. I520 at 7 (1937) (book value of a lease must be amortized over the life of the lease).

59 Matter of Underwriters Group Inc., Sec. Act Rel: I653 at I4 (I938). Cf. pp. 402-4 suppra.

${ }^{60}$ Accounting Rel. 7 at 7 ( 1938 ) (failure to state the mode followed by the registrant constitutes a material deficiency). Accord: Instruction 2, Instructions Pertaining to Balance Sheets of the Issuer, Form A-I at 29 (1937); Instruction Ir, Financial Statement Instruction Set No. I, Form E-r at 47; Schedule III, note (c), Instruction Book for Form A-2 at 42 (I937).

${ }^{6 r}$ Accounting Rel. 7 at 7 (1938); Instruction I3 $_{3}$ Financial Statement Instruction Set No. $x$, Form E-r at 47 (I937); Instruction 4, Instructions Pertaining to Balance Sheets of the Issuer, Form A-r at 29 (1937); Schedule V, Instruction Book for Form A-2 at 44 ( $x 937$ ). 
investments, ${ }^{62}$ debt discount and expense, ${ }^{63}$ or of other deferred charges. ${ }^{64}$

b) The second mode of assigning subsequent value to fixed assets is by appraisal. The concept of appraisal value which the Commission has standardized is well stated in the recent case of Matter of Breeze Corporation: ${ }^{65}$

If an appraisal or a representation of value purportedly based thereon, is not to be misleading the appraisal must meet two tests. In the first place as we have observed in in a previous opinion, ${ }^{66}$ an appraisal purports to be more than an arbitrary determination of value. It seeks to attach value to objects as a consequence of method. . . . In other words, it is misleading to represent as an appraisal a valuation which is not based solely on scientific method but which rests in whole or even in part upon foundations that are arbitrary or capricious. In the second place, ${ }^{67}$ there must be a fair and accurate application of the methods purported to be followed. Thus valuations contained in an appraisal purporting to follow certain norms, even though in the final analysis they represent merely informed judgments, nevertheless are representations that these norms have been accurately and fairly followed. If the norms purported to be followed are not fairly observed, the valuations finally arrived at are in essence misrepresentations of fact because they untruthfully describe the basis upon which judgment has been exercised. . . . The fact that valuations are in the final analysis expressions of judgment does not warrant departure from these standards.

c) Even if a fixed asset has been properly depreciated, the possibility remains that at the date of its abandonment it will appear that past estimates of the useful life of the asset were overly optimistic. The commission has a short answer to this problem. If a fixed asset has been abandoned $^{68}$ or has become worthless, ${ }^{69}$ the asset account ${ }^{70}$ and any developmental expense assignable ${ }^{7 x}$ thereto should immediately ${ }^{72}$ be written off against earned surplus.

62 Instruction 8, Instructions Pertaining to Balance Sheets of the Issuer, Form A-I at 30 (1937); Instruction 9 as to Balance Sheets, Instruction Book for Form A-2 at 32 (1937).

${ }^{6}{ }_{3}$ Instruction ${ }_{4}$, Instructions Pertaining to Balance Sheets of the Issuer, Form A-x at $3 \mathrm{I}$ (1937); Instruction 14, Financial Statement Instruction Set No. x, Form E-I at 47 (1937).

${ }_{64}$ Instruction 15 , Financial Statement Instruction Set No. I, Form E-I at 47 (I937).

${ }^{65}$ Sec. Act Rel. 1786 at 7 (1938).

${ }^{66}$ Matter of Haddam Distillers Corp., I S.E.C. 37,42 (I934).

67 Ibid. For cases in which these tests have been applied see notes $77,79-8 \mathrm{I}, 84$ and 88 infra.

${ }^{68} \mathrm{Sec}$ Matter of Golden Conqueror Mines Inc., Sec. Act Rel. I520 at 5 (1937). Cf. Matter of Metropolitan Personal Loan Co., Sec. Act Rel. I594 at 4 (I937), with pp. 402-4 supra.

69 Matter of American Gyro Co., I S.E.C. 83, 87 (1935). See Matter of Great Dike Gold Mines Inc., I S.E.C. 621,623 (1936).

$7^{\circ}$ Note 68 supra. The rule applies to current as well as to fixed assets. Instruction I, Financial Statement Instruction Set No. I, Instruction Book for Form E-I at 44 (I937).

${ }^{7}$ Matter of American Gyro Co., I S.E.C. 83, 87 (r935). See also Matter of Great Dike Gold Mining Co., I S.E.C. 62x, 623-4 (r936); Matter of Golden Conqueror Mines Inc., Sec. Act Rel. I520 at 5 (1937). (1937).

${ }^{22}$ But $c f$. Instruction Io (e), Financial Statement Instruction Set No. I, Form E-I at ${ }_{4} 6$ 
The above is what the commission has accomplished in standardizing the modes of valuating fixed assets. It is apparent that the steps which have been outlined are only suggestive of the wide possibilities of standardizing the conventions used in statements of financial condition. In the interest of insuring ready comparability of balance sheets, it would also be desirable to standardize balance sheet forms and to devise a uniform system of balance sheet accounts. This note dismisses as beyond its scope the commission's efforts ${ }^{73}$ to achieve these ends.

\section{B. ABANDONMENT OF MONEY VALUATIONS}

Far more novel, it would seem, is the second step that the commission has taken to secure the proper disclosure of unavoidable uncertainty, This step is the requirement that any stated value for fixed assets be abandoned if such value is without significance.

The commission has decided that if, at the date of acquisition of a fixed asset by the enterprise, the asset has not been valued in money in an armslength transaction, and if the assets for which the fixed asset is exchanged by the enterprise have not been valued in money in an arms-length transaction, the fixed asset may not be valued at a cost expressed in money terms. This limitation found in Form A-O-I ${ }^{74}$ is a reminder that even cost, that most simple and seemingly always available test of value, may be as illusory as any other measure of the value of fixed assets which is expressed in money terms.

If the commission concludes that it is inappropriate to assign a money value to a fixed asset, ${ }^{75}$ it requires the registrant to measure the cost of the fixed asset in the terms of the assets for which it was acquired. ${ }^{76}$ For example if the registrant has given I0,000 shares of its common stock for a mining property, and if neither the stock nor the property has been valued in an arms-length transaction, the registrant is required to disclose that the property was acquired for ro,000 shares of stock.

Understanding of the circumstances under which it is the commission's decision that appraised value be abandoned as materially misleading, requires familiarity with the cases in which the commission has held that,

73 Note 4 I supra.

${ }^{34}$ Item $\mathrm{I}_{3}(\mathrm{a})(\mathrm{c})$, Form A-O-I at 8 (x936); Schedule TV, Instruction Book for Form A-O-x at 9 .(I936) - Schedule K, Instruction Book for Form A-O-I at I4 (I936). Cf. Definition I6, Form E-I at 3 (I937) with Item 44, Form E-I at I7 (I937) and with Note D, Form E-I at 30 ( 1937 ).

75 But of. Matter of Platoro Gold Mines Inc., Sec. Act Rel. 1807 (1938). The possible inference from this case is that the requirements of Form A-O-I do not prohibit balance sheet valuations of fixed assets in the circumstances outlined in the text, but merely discourage them.

${ }^{6}$ Schedule K, Instruction Book for Form A-O-r at I4 (1936). 
because appraised value is misleading, it may not be employed. Since they merely illustrate the thesis that the investor is entitled to all presently knowable data which is pertinent to him, those cases ${ }^{77}$ will not be discussed in which untruth or omission has been predicated upon failure to

77 These cases are of two types:

(I) Cases in which the appraiser made no pretense of following scientific techniques. Matter of Great Dike Gold Mines Inc., I S.E.C. 621 , 626 (I936) (on the basis of a report made by "glancing" at the property, the registrant asserted that the mine was an "extremely promising project"); Matter of Gilpin Eureka Consolidated Mines Inc., I S.E.C. 752, 757 (I936) (valuation made by flashing a light on 75 feet of an 180 foot slope). Cf. Matter of Doris Ruby Mining Co., Sec. Act Rel. r884 at 5 (r939).

(2) Cases in which the appraiser purported to follow scientific techniques, but did not gather all the data which scientific method would require. This difficulty has arisen at practically all stages in the complicated process of appraising mining property. The commission has found it to be deficient to assign any value to ore when the ore body has not been subjected to any quantitative analysis (Matter of Gilpin Eureka Consolidated Mines Inc., I S.E.C. 752, 756, 758 (I936); Matter of Mining and Development Corp., I S.E.C. 786, 797 (I936); Matter of Gold Dust Mining \& Milling Co., Sec. Act Rel. 1654 as amended by Sec. Act Rel. 1749 a 2, 3, n. 2 (1938); Matter of Platoro Gold Mines Inc., Sec. Act Rel. I807 at 4 (1938) ) or when one dimension of the deposit is wholly unknown (Matter of Sunset Gold Fields Inc., 2 S.E.C. 329,334 (1937)) or when the volume of the ore was arrived at by multiplying together arbitrary dimensions (Matter of Livingston Mining Co., 2 S.E.C. I4x, I5० (I937); Matter of South Umpqua Mining Co., Sec. Act Rel. $x 694$ at 3 (1938)) or when the registrant has obtained insufficient samples from the deposit (Matter of La Luz Mining Corp., r S.E.C. 2I7, 222-3 (I935); Matter of Sunset Gold Fields Inc., 2 S.E.C. 329, 334 (1937); Matter of Rickard Ramore Gold Mines Inc., 2 S.E.C. 377, 387 (I937); Matter of Platoro Gold Mines Inc., Sec. Act Rel. 1807 at 4 (1938)) or has averaged samples without weighting them for variations in size of the bodies of ore which they represent (Matter of Franco Mining Co., I S.E.C. 285, 29 r (1936) ). Under any of these circumstances, the registrant may make no allegation of ore volume, of ore tonnage, or of assay results; nor may he assign money value to the ore. When quantitative data with respect to an ore body is known with a degree of exactitude sufficient to enable the registrant to describe the ore quantitatively, the registrant nevertheless may not make representations based on such data which convey the impression of being more precise than the data on which they are based. Matter of Gilpin Eureka Consolidated Mines Inc., I S.E.C. 752, 756, 758, (1936); Matter of Nat'l Boston Montana Mines, 2 S.E.C. 226, 257 (1937). Even if the registrant is able to state the tonnage and assay of the ore accurately, his representation of its value may be deficient for failure to consider all costs (including costs of selling or marketing) in determining the net recovery value of the ore (Matter of South Umpqua Mining Co., Sec. Act Rel. r694 at 3-4 (1938) ), for failure to ascertain costs of ore reduction at the level of production at which the registrant's ore reduction plant will probably operate (Matter of Sunset Gold Fields, 2 S.E.C. 329, 335 (r937) ) or for failure to discount the ore value to present worth (Matter of La Luz Mining Corp., I S.E.C. 2I7, 223 (r935); Matter of American Terminals and Transit Corp., I S.E.C. 7or, 7r9 (1936); Matter of Mining and Development Corp., I S.E.C. 786, 795 (1936); Matter of Emporia Gold Mines Inc., 2 S.E.C 209, 2 I8 (I937); Matter of Sunset Gold Fields Inc., 2 S.E.C. 329, 33I).

An appraised valuation resting upon guess rather than upon scientific method will be held to constitute an untrue statement if it exceeds the cost of the asset as previously defined, at least if the guess-work is not revealed. Matter of Gold Dust Mining \& Milling Co., Sec. Act Rel. 1654 as amended by Sec. Act Rel. 1749 at 4 (I938). Nor if a valuation rests upon surmise will it be cured by being reduced in a proportion, also determined by guesswork (ibid). 
rest appraised value upon data which the registrant should have obtained if he sought to follow an appraisal technique for which there was substantial authority, and which he could reasonably $7^{8}$ have obtained at the effective date of the registration statement.

In a number of different situations, however, the commission has held that appraised value is materially deficient, not because of any willful or negligent conduct on the part of the registrant in failing to gather data, but because, at the effective date of the registration statement, the registrant was unable to furnish sufficient facts upon which to rest appraised value. One instance of such inability occurs when it is impossible to reach the fixed asset in order to secure data. ${ }^{79}$ More important is that class of cases in which the registrant is unable to present an acceptable valuation of a fixed asset, because any appraisal must take into account as a factor the future demand for the registrant's product. If there are no circumstances justifying any assertions as to the future demand for the registrant's product, the commission holds that no appraised value may be assigned to the fixed asset. Thus the registrant may not set up intangible values upon the basis of expectation of future profit when the concern has no record of past profit, and when the future demand for its product is highly speculative. ${ }^{80}$ Nor may land and factory be appraised at reproduction cost new for a going distillery concern when the land and factory constituted an abandoned manufacturing site, and when no sale of comparable land and factory has been made in the vicinity in the recent past. ${ }^{8 x}$ It is now the general rule that the registrant may not value at reproduction cost new the fixed assets of an enterprise without a past record of profits when such valuation leads to a write-up of the assets above their cost to the enterprise. ${ }^{82}$

The general principle of this last group of cases has been embodied in Form A-O-I, which is used for the registration of mining corporations in a promotional stage. Assuming the registrant gives affirmative and satis-

${ }^{78}$ Note 38 snipra.

79 Matter of Franco Mining Co., I S.E.C. 285,290 (1936) and Matter of Emporia Gold Mines Inc., 2 S.E.C. 209, 220 (I937) (mines inundated); id. at $2 \times 9$ (ground frozen).

${ }^{80}$ Matter of American Gyro Co., I S.E.C. 83, 88 (I935) (registrant set up "good-will"); Matter of Peterson Engine Co., Sec. Act Rel. I629 at II (1937) (registrant assigned value to a patent).

${ }^{8 x}$ Matter of Continental Distillers and Importers Corp., I S.E.C. 54, 69, 75, 79, 8I (r935) (in this case the "rejproduction cost new" or "sound value" was included not in the balance sheet, but in the accountant's certificate and in the report of the appraiser).

${ }^{82}$ Note 53 silpra. In such circumstances it would seem that the registrant must at least reveal the cost of the assets to the enterprise. See pp. $443-44$ infra. 
factory answers to all items ${ }^{83}$ required by that form, he will have furnished the knowable data with respect to ore deposits which heretofore has been regarded as sufficient to support a money valuation of ore reserves. Any additional factors necessary in order to place a money value upon ore reserves are the estimated price at which the metal will be sold, the estimated life of the mine, and the corrective factor used to nullify any margin of error in computing the two factors last named. ${ }^{84}$ Because these three factors are estimates of whose validity there can be no objective test if the ore deposit is owned by a newly organized registrant which does not succeed to an established business, the commission enjoins a newly organized mining corporation from ascribing appraised values to its mines ${ }^{85}$ and at the same time requires disclosure of the basic data upon which appraised value was formerly thought to rest. ${ }^{86}$

\section{HISTORICAL FINANCIAL INFORMATION}

The instances outlined above in which the commission has required the registrant to abandon money valuation of fixed assets are all instances in which the registrant was an unseasoned enterprise. Some element of estimate goes into any valuation of a fixed asset, ${ }^{87}$ and accordingly an appraisal of the fixed assets of a "going concern" may be exposed to the objection that it involves the use of a method of valuation which employs

${ }^{8}$ The registrant is required to describe and state the present condition of each mining property operated by the registrant (Item 30(a), Form A-O-I at I8 (r936)), whether any ore bodies have been sufficiently developed to justify designation as proven or probable (Item 34, Form A-O-I at 20 (I936)), the weight or volume of proven and probable ore (Item 34A, Form A-O-x at $20 \mathrm{~A}$ ( 1936 ) (but not of ore neither proven nor probable (id.)), and the facts indicating the existence, in accord with registrant's claims, of any ore which is neither proven nor probable (Item 37, Form A-O-I at 22 (1936)). "Proven" ore means a block of ore so extensively surrounded by sampled faces that the risk of failure in continuity is reduced to a minimum, and "probable" ore means ore as to which the risk of failure in continuity is greater than for proven ore, but as to which there is sufficient evidence for assuming continuity of the ore. Instruction Book for Form A-O-I at 2. For illustrations of cases in which the commission has held that no quantitative data may be presented with respect to ore deposits and that consequently the ore may not be denominated as "proven" or "probable," see note 77 supra.

Other data which a registrant on Form A-O-I is called upon to present include the methods employed in sampling ore and the number of samples taken (Item 33, Form A-O-I at 20 (I936)), the total estimated cost of recovery per unit of weight or volume of crude proven or probable ore (Item $34 \mathrm{~B}$, Form A-O-I at $20 \mathrm{~B}$ ( 1936 ) ), the proposed plan of exploration, development, and operation of the mines (Item $3 \mathrm{I}$, Form A-O-I at $I_{9}$ ( $\left.\mathrm{r}_{93} 6\right)$ ), the three principal markets for each constituent of the ore not to be sold for its metallic content (Item 35, Form A-O-I at 2 I $\left(x_{93} 6\right)$ ), and the specific basis of any special value claimed for any mining property operated by the registrant (Item 38, Form A-O-I at 23 (1936)).

${ }_{4}$ Cf. Matter of Monitor Gold Mining Co., Sec. Act Rel. I874 at I (r939).
${ }_{55}$ Pp. 4I4-I 5 supra.
${ }^{86}$ P. 4 I6 supra.
${ }^{87}$ Pp. 407-8 supra. 
doubtful factors in such a manner as to resolve a preponderance of doubt in favor of the owner of the assets. ${ }^{88}$ In spite of this fact, the forms which are not forms used solely for the registration of unseasoned enterprises rely upon techniques other than the abandonment of fixed asset valuation to bring out the uncertainties inherent in fixed asset valuation.

The first of these techniques, disclosure of historical financial information, is predicated upon the theory that information with respect to the entries summarized in the balance sheet accounts will enable the investor to face risks more intelligently by enabling him to project into the future trends observable in the course of the registrant's past history. ${ }^{89}$

The importance and prevalence of historical information are suggested by the view of Commissioner Healy that the balance sheet is more accurately regarded as a recapitulation of the financial history of the enterprise than as either a statement of the value of the enterprise at the balance sheet date or as a prediction of the money figures at which claims by or against the enterprise will be realized. ${ }^{90}$ As an historical record, however, the balance sheet is inadequate since it portrays the result of past accounting entries but does not disclose their details. It may be assumed that the corporation which followed customary standards of financial reporting as they were formulated prior to the Securities Act took cognizance of this inadequacy, and presented the prospective investor with a profit and loss statement and perhaps a statement of surplus for the accounting period preceding investment. In its requirements as to the provision of historical financial information, the commission has sought in the first place to standardize and improve the quality and quantity of information customarily provided through the medium of the profit and loss statement and the statement of surplus.

${ }^{88}$ Matter of Plymouth Consolidated Gold Mines, I S.E.C. I39, I45 (I935) (assignment of value to an ore body on the basis of sampling its richest areas); Matter of Oklahoma-Texas Trust, Sec. Act Rel. $x_{5} 6_{3}$ at $x_{5}$ (I937), aff'd. roo F. (2d) 888 (C.C.A. roth 1939) (resolution of all doubtful factors involved in use of the volumetric method of determination of oil reserves in favor of the registrant); Matter of Breeze Corp., Sec. Act Rel. 1786 at ro (1938) (valuation of intangibles on the basis of a sales volume over double that the registrant had had in the past; this sales volume was obtained by making an admittedly arbitrary calculation of a percentage of an estimated national demand which the registrant would serve); Matter of Monitor Gold Mining Corp., Sec. Act Rel. I874 at 2 (I939) (a valuation obtained by reduction of estimated future return to present worth was held materially deficient because it employed a rate of capitalization which greatly underestimated the risk attendant upon valuation of mining property in this manner). Cf. Matter of Big Wedge Mining Co., I S.E.C. 98, ro3 (1935).

${ }^{89}$ See Sanders, Accounting Aspects of the Securities Act, 4 Law and Contemp. Prob. I9I, 206 (I937).

${ }^{\circ 0}$ Healy, op. cit. supra note I9, at 8; see also Sanders, op. cit. supra note 89, at 195 . 
In its treatment of the profit and loss statement the commission's reforms have proceeded along three general lines: standardization of the function of the profit and loss statement, segregation in the profit and loss statement of items significantly different, and extension of the time period for which information as to operations is required.

The commission has established that the function of the profit and loss statement is to portray changes in earned surplus ${ }^{9 x}$ resulting from earnings or losses in the accounting period for which the statement is furnished. ${ }^{2}$ Commonplace as this proposition may appear, the commission has had occasion to apply it in several cases. It has been held, for example, that contributions should not be included in the profit and loss statement as earned income and may only be validly set up as donated surplus; $;^{93}$ that if the registrant sets up the expense of developing an asset during an accounting period in the asset account "development expense," it is improper accounting practice to reflect income from the asset attributable to the same accounting period in the profit and loss statement; ${ }^{94}$ and that, if the period of development of a fixed asset has ceased, it is improper to debit expenses incurred in operations in the asset account, developmental expense, and to fail to charge them to profit and loss.95 The above decisions point toward the adoption by the commission of the so-called "accrual" basis of allocating income and expense. Nothing to the contrary follows from the decision that a paper profit obtained by accepting in settlement of a debt an evidence of indebtedness with greater face value than the amount of the debt may not be treated as income until realized ${ }^{96}$ since accountants who follow an "accrual" basis

\footnotetext{
9x Financial Statement Form No. 2, Form E-I at 37, 39 (I937); Item 55, Form A-r at 24, 27 (1937).

${ }_{92}$ Accounting Rel. 7 at 6 (I938).

93 Matter of General Income Shares Inc., I S.E.C. Iro, II3 (1935); Matter of Nat'l Educators Mutual Ass'n, I S.E.C. 208, 214 (r935); Autostrop Safety Razor Co. v. Comm'r, 28 B.T.A. 62I, aff'd 74 F. 2(d) 226 (C.C.A. 2d 1934); United States v. Oregon-Washington Ry. and Nav. Co., 25I Fed. 2II (C.C.A. 2d I9r8); Finney, Principles of Accounting c. 38 at 6 (I93I); Kester, Advanced Accounting 36r (r933); Montgomery, Auditing Theory and Practice 4I4 (I934).

94 The Commission remarked in the American Terminals and Transit case that "accountants generally advocate that all income from a property in development be applied in reduction of development expense capitalizing only the excess of expense over income." I S.E.C. 7or, 7ro (1936).

${ }_{95}$ Matter of Virginia City Gold Mining Co., Sec. Act Rel. I6I5 at 2 (I937).

${ }_{56}$ Matter of Metropolitan Personal Loan Co., Sec. Act Rel. I594 at 4, 7 (1937). See Matter of General Income Shares Inc., I S.E.C. IIO, II2 (I935); I Finney, Principles of Accounting c. 2 at 2 (I93I); Paton, Accountants' Handbook ro76 (I934); Kester, Advanced Accounting 492 (1933).
} 
in timing income agree that conservative practice requires no income to be taken until it is both accrued and realized. ${ }^{97}$

It is beyond the scope of this note to make a detailed examination of the promulgated forms of profit and loss statements in order to show the extent of segregation of classes of income and expense and particularity of description which they require. The elaborate and detailed disclosure required by the forms has been commented on elsewhere, ${ }^{98}$ and is well illustrated by the commission's decision that it constitutes a deficiency to characterize unusual and non-recurrent income as "other income" without making explanation of its non-recurrent character. ${ }^{99}$

The commission's third reform of the profit and loss mode of presenting financial information has been to require profit and loss statements for at least the three years in the life of the enterprise immediately preceding registration. ${ }^{100}$

While differing as to the exact disclosure required by means of historical statements of surplus supplementary to the profit and loss statements, the forms agree in requiring much that was not formerly customary. For example, Form A-2 demands for the accounting period preceding registration a schedule of surplus showing additions and charges to capital surplus segregated from additions and charges to earned surplus, ${ }^{\text {xox }}$ and in support of every required profit and loss statement Form A-2 requires a schedule of income from dividends. ${ }^{\mathrm{x} 02}$ Other forms enjoin the registrant to submit statements of earned ${ }^{\mathrm{x} 03}$ and/or paid-in ${ }^{\mathrm{T04}}$ and/or capital ${ }^{\mathrm{x05}}$ surplus for each period for which profit and loss statements must be furnished.

The most important innovations introduced by the commission with respect to historical financial analysis consist in extending the historical mode of analysis to accounts other than the surplus account, and in extending the time period of historical analysis.

To illustrate the value of the former: Suppose the registrant develops a mine, begins active operations, and suffers losses which it conceals by writing-up the value of the mine. No profit and loss statement, statement

97 Note 184 infra.

98 Sanders, op cit. supra note 89, at 207.

99 Matter of American Terminals and Transit Co., x S.E.C. 7or, 708 (I936).

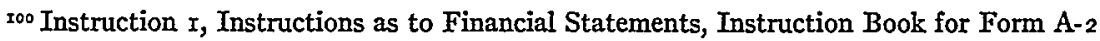
at 22 (1937); Item 55, Form A-I at 24 (I937); Exhibit Q, Form E-r at 22 (r937).

${ }_{\text {ror }}$ Schedule VII, Instruction Book for Form A-2 at 46 (I937).

${ }^{102}$ Schedule IX, Instruction Book for Form A-2 at 48 (1937).

${ }_{{ }_{103}}$ Financial Statement Form No. 2, Form E-I at 39 ('́937); Item 55, Form A-r at 27 (I937). ${ }^{104}$ Instruction 22, Financial Statement Instruction Set No. I, Form E-r at 49 (r937). ${ }^{205}$ Instruction 23, Financial Statement Instruction Set No. I, Form E-I at 49 (I937). 
of surplus, or balance sheet would disclose the erroneous practice. But a schedule of property, plant, and equipment would reveal the overstatement. Accordingly, the principal forms for registration used by concerns which are not newly organized at the date of registration require the registrant to disclose the nature and details of transactions giving rise to any substantial unrealized appreciation or write-down of property, plant, and equipment ${ }^{\mathrm{x} 06}$ since January $\mathrm{I}, \mathrm{I} 922,{ }^{\mathrm{I0}}$ with a statement of the contra accounting entries and related adjustments in reserves. ${ }^{\text {xo8 }}$ Like information since January $I, 1922$, is required for intangible assets ${ }^{109}$ and investment $^{\text {ro }}$ accounts. Form A-2 further requires the registrant to include a schedule for the accounting period preceding registration of the credits offsetting debits to the following accounts: maintenance and repairs; depreciation, depletion and amortization; taxes; management and service contract fees; and rents and royalties. ${ }^{\mathrm{Ix}}$

All basic forms used by concerns which are not in a promotional stage require that the registrant reveal the methods used in setting up reserves for depreciation, depletion, or amortization, ${ }^{112}$ the debits and credits to

${ }^{x_{0}}$ Instruction ro, Financial Statement Instruction Set No. r, Form E-r at 46 (I937).

${ }^{207}$ Instruction I, Instructions Pertaining to Balance Sheets of the Issuer, Form A-I at 29 (I937).

${ }^{208}$ Item 45, Form A-2 at II (I937). Form A-2 also requires the filing of a schedule which shows the accounting entries to property, plant and equipment during the last accounting period. Schedule II, Instruction Book for Form A-2 at 4I (I937).

${ }^{209}$ Instruction I2(a), Financial Statement Instruction Set No. I, Form E-I at 47 (I937); Instruction $3 \mathrm{~B}$, Instructions Pertaining to Balance Sheets of the Issuer, Form A-I at 29 (1937); Item 45, Form A-2 at II (I937). Form A-2 also requires a schedule of debits and credits to intangibles and offsetting entries during the last accounting period. Schedule IV, Instruction Book for Form A-2 at 43 (1937).

rro Item 45, Form A-2 at II (I937); Schedule I, Instruction Book for Form A-2 at 39 (I937) (investments in securities of affiliates during accounting periods for which profit and loss statements are required to be furnished); Instruction 5, Instructions Pertaining to Balance Sheets of the Issuer, Form A-r at 30 (r937) (accounts in which any differences between cost and ledger value of securities of affiliates are reflected as of the date of registration); Instruction 6(b)(c), Instructions Pertaining to Balance Sheets of the Issuer, Form E-r at 45 (r937) (difference between cost and ledger value of securities of affiliates and accounts in which the difference is reflected).

Irx Schedule VIII, Instruction Book for Form A-2 at 47 (I937).

${ }_{12}$ Instruction 2A, Instructions Pertaining to Balance Sheets of the Issuer, Form A-I at 29 (I937); Instruction 4, Instructions Pertaining to Balance Sheets of the Issuer, Form A-I at 29 (1937); Instruction 8, Instructions Pertaining to Balance Sheets of the Issuer, Form A-I at 30 (1937); Instructions $1_{4}$, Instructions Pertaining to Balance Sheets of the Issuer, Form A-I at 3 I (I937); Instruction I5, Instructions Pertaining to Balance Sheets of the Issuer, Form A-r at 3 I (1937); Instruction 9, Financial Statement Instruction Set No. I, Form E-I at 46 (I937); Instruction II(a), Financial Statement Instruction Set No. r, Form E-r at 47 (r937); Schedule III, note (c), Instruction Book for Form A-2 at 42 (I937); Schedule V, note (I)(b), Instruction Book for Form A-2 at 44 (1937). 
those reserves for various periods, ${ }^{\mathrm{II} 3}$ the contra accounts involved in their creation, ${ }^{\text {II } 4}$ and in two forms a detailed statement of previous allocation of depreciation for income tax purposes as compared with its allocation for dividend purposes. ${ }^{\text {II }}$

Another striking way in which the commission has promoted historical analysis of business conditions is by extending the period of analysis. It was indicated above that the commission projects historical analysis into the past by requiring profit and loss statements and statements of surplus for at least three years ${ }^{\mathrm{Ir} 6}$ and historical analysis of certain accounts for as many as fifteen years. ${ }^{\mathrm{II} 7}$ There remains for consideration the commission's effort to require the registrant to project its business condition into the immediate future in such manner as to empower the investor to visualize the condition of the registrant immediately following the distribution of the registered securities, and, in addition, to enable him to ascertain the risk he assumes that the balance of the securities will never be distributed.

The forms for registration accordingly require disclosure of such matters as: the proceeds ${ }^{1 \times 8}$ to the registrant expected to be realized from the sale of securities; $;^{\text {II9 }}$ the proposed disposition of the monies received ${ }^{\mathrm{I20}}$ from

${ }^{113}$ Form $A-2$ requires this information for only the accounting periods for which balance sheets must be furnished, Schedules III and V, Instruction Book for Form A-2 at 42, 44 (1937); but of. Item 45, Form A-2 at II (1937) (changes in property accounts since January r, r922). Form A-I requires the registrant to state the methods used in creating reserves for amortization of intangibles since January $I$, rg22. Instruction 4, Instructions Pertaining to Balance Sheets of the Issuer, Form A-r at 29 (I937).

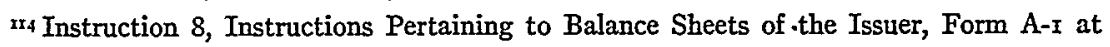
30 (I937).

${ }_{15}$ Instruction 2, Instructions Pertaining to Balance Sheets of the Issuer, Form A-I at 29 (1937); Instruction Ir, Financial Statement Instruction Set No. I, Form E-r at 47 (I937).

${ }^{\text {r16 }}$ Note IoO supra.

II7 Notes ro7-9 supra.

${ }^{128}$ By "proceeds" is meant sale price less expenses of distribution.

Ir9 Item 26, Form A-x at 8 (I937); Item 4O(a), Form A-O-I at 24 (I936); Item x8(a), Form A-O-I at IO (I936); Item I7, Form A-O-I at Io (I936) (detailed explanation if the proceeds from the sale of the registered securities are not to be received by the registrant); Item $27(\mathrm{c})$, Form A-2 at 8 (I937); Item 30, Form E-I at $x_{4}$ (I937); $c f$. Item 8, Form E-I at 6 (I937). A statement of estimated proceeds is false if it exceeds the face value of the securities available for sale to the public. Matter of Nat'l Boston Montana Mines Corp., 2 S.E.C. 226, 245 (1937).

${ }_{x 20}$ The forms require that the registrant make: (I) a statement of underwriting discounts or commission paid or to be paid (notes $\mathrm{I} 59$, I $7 \mathrm{X}$, and $\mathrm{I} 74$ infra); (2) a summary and itemization of other expenses in connection with sale of the securities (Item $27(\mathrm{~b})$, Form A-2 at 8 (I937), Item I8(c), Form A-O-I at 1o (I936); Item 37, Form A-I at I2 (1937); Item 29, Form E-x at I $_{4}$ (1937) ); (3) a reasonably itemized statement of the purposes for which the net proceeds (gross proceeds less all expenses of distributing the registered issue) are to be used (Item 28, Form A-2 at 8 (1937); Item 27, Form A-I at 8 (1937); Item 32, Form E-I at I5 (r937); 
sales of the registered securities ${ }^{12 x}$ and any changes in such disposition which would result from the ripening into actuality of contingencies which can be anticipated; ${ }^{122}$ the estimated funds to be received by the registrant from sources other than the sale of the registered securities ${ }^{123}$ and the funds which the registrant must so receive if it is to carry out successfully the business program envisaged at the effective date of the registration statement. ${ }^{124}$ One form requires the registrant to furnish a pro forma balance sheet which gives effect to the proposed securities distribution, ${ }^{\text {,25 }}$ but seemingly no pro forma balance sheet may be furnished by the registrant as part of a prospectus unless an underwriter is under a

Item 43, Form A-O-I at 25 (I936)); and (4) a description of property to be purchased with the proceeds of the registered issue (Item 40, Form A-I at 3 (I937); Item 29, Form A-2 at 8 (I937); Item 32, Form E-I at I5 (I937)).

rzx Failure to state and itemize this data constitutes a material deficiency. Matter of West Park Apts. Corp., Sec. Act Rel. I8II at 9 (1938) (construction of Item 37, Form A-I at x2 (1937)).

Answers to these items have been condemned: (I) for vagueness (Matter of Lewis American Airways, r S.E.C. 330,343 (1936) (statement that the money will be used for "development and completion to marketable state" of an aircraft invention or in the alternative for "general corporate uses"); Matter of Consolidated Mines Syndicate, 2 S.E.C. 3I6, 323 (I937) (statement that money will be used for "operation and administration expense" when no further statement was made as to allocation of funds among the registrant's several properties)); (2) for failure to state all the known facts with respect to disposition of the proceeds (Matter of Consolidated Funds Inc., Sec. Act Rel. I548 at 3 (x937) (statement that the funds would be used to purchase securities or other property to be held by the issuer as investments without further disclosure of companies in which the registrant intends to invest at the effective date of the registration statement); Matter of Crusader Aircraft Corp., Sec. Act Rel. I677 at 4 (r938) (if the registrant is without funds at the effective date of the registration statement, it must list current liabilities in answer to these items). Cf. Matter of Paper Sales Co. of Detroit, Sec. Act Rel. I556 (1937) ); (3) for failure to disclose clearly any areas of doubt as to the disposition of the funds: this objection may be raised when the registrant confidently states that it will use funds for certain purposes and the statement is a mere guess (Matter of Emporia Gold Mines Inc., 2 S.E.C. 209, 216 (1937); Matter of Nat'l Boston Montana Mines, 2 S.E.C. 226, 246 (1937); Matter of Crusader Aircraft Corp., Sec. Act Rel. x677 at 4 (1938) ), or when the registrant furnishes a detailed statement of uses to which funds will be put when reasonably prompt expenditures of the nature indicated are not warranted (Matter of Emporia Gold Mines Inc., 2 S.E.C. 209, 216 (r937); Matter of Consolidated Mines Syndicate, a S.E.C. 3 I6, 323 (I937)).

An estimate that funds will be used for a given purpose may be shown to have been made in bad faith and hence to be false and deficient by evidence, that funds were never thereafter used for the given purpose. Matter of Nat'l Boston Montana Mines Corp., 2 S.E.C. 226, 246 (1937).

${ }^{222} \mathrm{Cf}$. Item 43, Form A-O-I at 25 (1936). But even if a form does not call for this information explicitly, it must be given. Matter of Mining and Development Corp., I S.E.C. 786, 808 (1936); Matter of Bering Straits Tin Mines Inc., Sec. Act Rel. $1_{498}$ at 7 (1937); Matter of Queensboro Gold Mines Ltd. Sec. Act Rel. I6I 7 at 2 (1937).

${ }_{23}$ Item 40 (b), Form A-O-I at 24 (I936); Item 30(b), Form E-I at ${ }_{4}$ (1937).

224 Item 4I, Form A-O-I at 24 (I936). r25 Exhibit S, Form E-I at 22 (1937). 
firm commitment to effect the distribution of which the pro forma balance sheet expresses the result. ${ }^{.26}$

\section{SUPPLEMENTARY INFORMATION}

The commission's elaborate regulations to assure disclosure of the separate entries summarized in the balance sheet fixed asset accounts enable the investor to be cognizant of the risks concealed by the assignment of balance sheet values to fixed assets. The requirement that securities issuers reveal historical financial information is, however, far from the only device used by the commission to bring to the attention of investors unavoidable uncertainties glossed over by the illusory exactitude of balance sheet values. The commission, for example, minimizes the misleading effect of balance sheet valuations by requiring the registrant to disclose any divergence between cost and market ${ }^{127}$ value of marketable securities; $;^{128}$ betwieen ledger and market value ${ }^{\mathrm{r} 29}$ and $\cos ^{\mathrm{r} \mathrm{t}^{30}}$ of securities held for investment; and between cost, ledger value, and unrealized appreciation in value of property, plant and equipment, ${ }^{{ }^{3 x}}$ and intangibles. ${ }^{132}$

${ }^{126}$ Matter of Haddam Distillers Corp., I S.E.C. 48, 53 (1934); Matter of Continental Distillers and Importers Corp., I S.E.C. 54, 78 (I935).

${ }^{227}$ Market value may be determined as of the balance sheet date (Instruction 3, Financial Statement Instruction Set No. I, Form E-I at 44 (I937); Instruction 6, Financial Statement Instruction Set No. I, Form E-I at 45 (x937)), or it may be determined as of the nearest available date to that of the balance sheet. $C f$. Instruction 6, Financial Statement Instruction Set No. I, Form E-x at 46 (I937). To assign a market value to a security implies that the security has a definitely determinable market value. Instruction 6(a) (9), Financial Statement Instruction Set No. I, Form E-I at 45 (I937).

${ }^{228}$ Instruction 3, Financial Statement Instruction Set No. x, Form E-I at 44 (I937). But under Form A-2 the requirement is that if marketable securities are not valued at market, that current market quotations must be shown in the balance sheet parenthetically. Instruction 2, Instructions as to Current Assets, Instruction Book for Form A-2 at 3I (I937). Form A-I only requires the basis of the valuation to be given. Instruction II, Instructions Pertaining to Balance Sheets of Issuer, Form A-I at 30 ( 1937 ).

${ }_{329}$ Schedule IA, Instruction Book for Form A-2 at 40 (I937).

${ }^{3_{3}}$ Instruction 6A, Instructions Pertaining to Balance Sheets of the Issuer, Form A-I at 30 (I937); Instruction 7(b), Financial Statement Instruction Set No. I, Form E-I at 46 (1937); Item 45(a), Form A-2 at II (I937) (this item only requires valuation at cost or appraised value if the security had been valued at cost since January $I, I 922)$.

I3I Instruction IA(a)(b)(d), Instructions Pertaining to Balance Sheets of the Issuer, Form A-I at 29 (1937); Instruction 24, Instructions Pertaining to Balance Sheets of the Issuer, Form A-I at 32 (I937); Instruction Io, Financial Statement Instruction Set No. I, Instruction Book for Form E-I at 46 (1937); Schedule II, Instruction Book for Form A-2 at 4I (I937) (only applies to accounts altered during the accounting periods for which balance sheets must be furnished); Item 45(a), Form A-2 at II (I937) (only calls for cost incurred and revaluation made since January $I, x_{922}$ ).

$x_{32}$ Instruction I2, Financial Statement Instruction Set No. I, Form E-I at 47 (1937); Schedule IV, Instruction Book for Form A-2 at 43 (I937) (only applies to accounts altered 
While the required data with respect to cost might be regarded as purely historical, and not intended to shed any light upon the uncertainty inherent in assignment of present value, such is not true when the cost is one incurred shortly before registration.

The commission also exacts disclosure of the cost to insiders of property acquired or to be acquired by the registrant from insiders other than in the ordinary course of business and within two years of filing of the registration statement. ${ }^{x 3}$ The investor consequently is afforded a graphic illustration of the business risks which make possible radical divergence between cost of fixed assets to insiders and the value of those assets to the business enterprise.

A third technique used by the commission to impeach the definitive character of fixed asset valuations may be termed the descriptive technique. Qualitative description has always been an important element of security selling literature. Unfortunately the description has as often as not been of facts wholly immaterial to the investor. ${ }^{134}$ The commission has sought to make the descriptive technique a real instrument of disclosure of unavoidable risk.

The use of this technique is well illustrated by the cases which have construed the items in the forms which exact disclosure of the character of the business done and to be done by the registrant. ${ }^{35}$ In Matter of Vir-

during the accounting periods for which balance sheets must be furnished); Item 45(a), Form A-2 at II ( 1937 ) (only calls for cost incurred or revaluation since January $\mathrm{I}, \mathrm{rg22}$ ). Cf. Instruction $3^{B}$, Instructions Pertaining to Balance Sheets of the Issuer, Form A-x at 29 (I937) (comparative statement of cost and ledger value of each class of intangibles since January $I$, 1922, with a complete statement of the differences if any).

${ }_{33}$ Form A-I does not expressly require cost of property to insiders to be stated. But Item 45 of that form has been construed to require disclosure of the cost to certain insiders of any property acquired or proposed to be acquired from such insiders other than in the ordinary course of the registrant's business and within two years of the filing of the registration statement. (Item 45, Form A-r at I5 (1937); Matter of Plymouth Consolidated Gold Mines Ltd., I S.E.C. I39, I44 (I935); Matter of La Luz Mining Corp., r S.E.C. 217, 223 (1935); Matter of Mining and Development Corp., I S.E.C. 786, 792 (I936). Other forms specifically require disclosure of cost to insiders (Item I2(b)(c), Form A-O-I at 7 (I936); Item 27, Form E-r at $x_{4}$ (r937); Item 35, Form A-2 at 9 (I937)) although differing somewhat as to the proper definition of "insiders."

${ }_{34}$ See Sears, The New Place of the Stockholder $x_{40}$ (I929).

$x_{35}$ Item 3, Form A-I at I (1937); Items 3, 4, Form A-O-I at 2 (I936); Item 5, Form E-I at 6 (1937); Item 5, Form A-2 at I (I937). The general rule for answering these items is that they do not relate to the powers and objects specified in the charter of the registrant business but to the actual business done and to be done, and that consequently to answer the items by stating the kind of business done or to be done will not be adequate. Instructions as to Items 3 and 4, Instructions as to Particular Items of the Form, Instruction Book for Form A-O-r at 3 (I936). 
ginia City Gold Mining Co., ${ }^{{ }^{3}{ }^{6}}$. for example, by stating that it was engaged in development work the registrant avoided the common trap of asserting that it was engaged in "mining" when it was not then engaged in extracting ore for sale in the market. ${ }^{37}$ Nor does it appear that the registrant's statement that it would engage in mining in the future was deficient for failure to state the probable minimum period intervening before profitable production. ${ }^{{ }^{38}}$ The commission nevertheless found that the registrant's assertion that it was engaged in developmental work held forth an allure of future profit and was therefore deficient in the absence of disclosure of the registrant's past history of operating losses.

\section{E. NAME AND PRICE}

The preceding discussion has been of the techniques employed by the commission to effectuate disclosure of facts necessary for informed analy-

${ }^{\mathrm{r}}{ }^{6} \mathrm{Sec}$. Act Rel. I6r5 at 2 (I937).

$I_{37}$ The general rule, that it is improper to state that a certain business is being done unless it is being done at the date of registration, has been applied in two situations. ( $I$ ) When the registrant's answer conveys the impression that the registrant is carrying on a business in which it has never been employed. In Matter of Lewis American Airways, I S.E.C. 330, 343 (1936) the registrant stated that its business was the "manufacture, sale and repair of motor vehicles and airships." In holding this answer deficient the commission remarked, "the evidence at the hearing quite clearly disclosed that not even one model of the airmobile has been completed and that only one of the proposed airplanes is at present in existence. . . . The registrant should have disclosed that it had only completed one airplane which had not been tested by the Department of Commerce nor even successfully flown." Cf. Matter of Crusader Aircraft Corp., Sec. Act Rel. ${ }_{677}$ ( I93 $_{9}$ ). A statement that the registrant is engaged in gold mining is deficient when the only gold produced had been in connection with developmental work. Matter of Sunset Gold Fields Inc., 2 S.E.C. 329, 335 (1937). Cf. Matter of Great Dike Gold Mines Inc., I S.E.C. 62I, 626 ( 1936 ). A statement that a certain business is carried on is deficient when at the effective date of the registration statement, the registrant does not own the equipment to enable it to carry on that business. Matter of Consolidated Mines Syndicate, 2 S.E.C. 316,323 (1937). (2) When the registrant's answer conveys the impression that it is carrying on a business in which it has ceased to engage. Matter of Canusa Gold Mines Ltd., Sec. Act Rel. $1_{507}$ at ${ }_{3} 3$ (statement that the registrant is engaged in mining when its sole source of product has been depleted); Matter of Commonwealth Bond Corp., I S.E.C. I3, x9, I8 F.T.C. 635,643 (I934) (statement that the registrant is selling bonds when for a number of years its sole activity has been the reorganization of its defaulted issues).

${ }_{23}^{8}$ Matter of Major Metals Corp., 2 S.E.C. 74, 76 (1937) (registrant's assertion that it proposed to examine certain mining properties and on the basis of such examination to acquire, rehabilitate and bring them into profitable production held deficient for failure to state that such examination would take time and that experience in the mining industry indicated that profitable production would be still further deferred, and that operation at a profit, which might profitably be applied to interest charges, might well begin only after three or four years). A registrant's prophecy of future profits will be held deficient if the great preponderance of evidence is against such opinion being valid (Matter of American Kid Co., I S.E.C. 694, 697-9 (I936)) or if the future profits of the registrant are entirely conjectural (Matter of American Terminals and Transit Co., I S.E.C. 7or, 739-40 (1936)). 
sis of unavoidable risk and its commensurate or non-commensurate relation to rate of return. The commission, however, has also undertaken to aid the investor who relies, not upon informed analysis of the enterprise in which he invests, but, instead, upon the good or bad name of the enterprise or upon the trend of the prices at which its securities are sold.

To protect those who may rely upon the name of the enterprise, the commission will hold a registration statement deficient if the registrant has a name which the investor is likely to confuse with that of another existing company, ${ }^{\mathrm{r} 39}$ at least if the registrant does not clearly distinguish itself from the similarly named enterprise. ${ }^{14^{\circ}}$ In this type of litigation the commission considers trade name cases to be valuable precedents. ${ }^{\mathrm{Ix}}$

More important is the disclosure required by the Commission with respect to the significance of the price at which the registered issue is to be offered to the public. The process of securities distribution frequently involves the sale of the security in large blocs, its resale in smaller blocs, and its further resale in still smaller blocs until eventually small holdings percolate down to "Main Street" investors. ${ }^{142}$ The distribution price for a security is hence apt to be fixed, not by the action of small investors, but by the action of large purchasers of the issue. Large investors, if perfectly informed of risks inherent in investment in the registrant and if they purchase in a perfect market, will fix a price which reflects the security's value as estimated by the most informed persons. The small investor will obtain the benefit of this price no matter how uninformed he may be. If, however, the market for a security is for some reason ${ }^{\mathrm{I} 43}$ not a perfect market, this happy condition may not be realized.

The commission consequently has been alert to require that the registrant reveal any divergence between the price at which the security is offered, and the price of the security as it would be determined in a perfect market. ${ }^{\mathrm{I} 44}$ Accordingly if the registrant states a flat price at which

${ }_{39}$ Matter of Nat'l Educators' Mutual Ass'n, I S.E.C. 208, 2 I2 (1935) (National Educators' Mutual Ass'n Inc.-National Education Ass'n); Matter of Gold Hunter Extension Inc., Sec. Act Rel. 18I3 at 2 (1938) (Gold Hunter Extension Inc.-Gold Hunter Mine). Cf. Matter of Securities Exchange Corp., Sec. Ex. Act Rel. 1395 (1937) (Securities Exchange Corp.-Securities and Exchange Comm'n).

×40 Matter of Gold Hunter Extension Inc., Sec. Act Rel. 1813 at 3 (1938).

${ }_{14} I d$. at 2,3 .

${ }^{142}$ Pp. 430-34 infra.

${ }^{243}$ Lack of mobility of buyers or sellers and lack of perfect competition are the most notable causes of the imperfect character of markets.

I44 The following items require the disclosure of the price at which each registered security is proposed to be offered to the public, and, if the price is not a fixed price, the method by which the offering price will be computed. Item 34, Form A-I at II (1937); Items r8, 19, Form A-O-r 
the security will be offered to the public, he need not disclose that the recent price of the security was lower than the offering price, ${ }^{145}$ since the public is given fair warning that it is purchasing at a price determined by the issuer, and not at one determined by impartial market forces. ${ }^{{ }^{4} 6}$

If the registrant, however, indicates that the security will be offered at the market price, the commission takes the position that "the investor is entitled to knowledge of any artificial restraint upon the flow of the security into the market and of any past or possible artificial future demand for the security so that he may determine for himself to what extent the market price represents the collective judgment of buyers and sellers as to the merits of the security rather than a price induced by abnormal demands for and abnormal restraints upon the security." ${ } 47$ In carrying out

at Io, II (I936); Item 24, Form A-2 at 8 (I937); Item 33, Form E-I at I5 (I937). Item 22 of Form A-O-I requires the registrant to state whether any person or persons to the knowledge of the registrant are to maintain a market for any of the securities being registered. For a discussion of Item 36, the analogous provision of Form C-I for investment trusts, see Matter of T.I.S. Management Corp., Sec. Act Rel. 1689 (1938). On the basis of the disclosure required by the above items, it is apparent that the commission is interested in obtaining disclosure of restraints upon normal market forces from whatever source they arise. The Securities Exchange Act of 1934 attacks the problem of divergence between theoretical and actual market price by prohibiting certain purposive activity aimed at producing that divergence. See 46 Yale L. J. 624 (1937).

${ }^{245}$ Matter of South Umpqua Mining Co., Sec. Act Rel. 1694 (1938).

${ }^{{ }^{4} 4^{6}}$ See Matter of Austin Silver Mining Co., Sec. Act Rel. $\mathrm{I} 774$ at 7 (I938). But $c f$. Matter of Old Diamond Gold Mines Ltd., Sec. Act Rel. 1576 at I (1937) (held materially misleading for a registrant to disclose a past competitive market price of $47 \%$. a share and to state that the stock would be publicly offered at 30 f. a share when the registrant did not also disclose that as of the effective date of the registration statement the competitive market price of its stock was from $3 \xi$. to $5 k$. a share). The registrant may not state that securities will be sold by a "step-up" scheme without disclosing that the sole purpose of the scheme is to stimulate security sales by giving the underwriter a "buy-now" argument. Matter of Snow Point Mining Co. Inc., I S.E.C. 3II, 318 (I936); Matter of Avocalon Extension Syndicate Ltd., I S.E.C. 657, 659 (1936).

${ }^{447}$ Matter of Rickard Ramore Gold Mines, 2 S.E.C. $377,3^{85}$ (1934). Cf. Instructions as to Item I9, Instructions as to Particular Items of the Form, Form A-O-I at 4 (I936); Instruction as to Item 24, Instructions as to Particular Items of the Form, Instruction Book for Form A-2 at 8 (I937). But the registration statement is not deficient for failure to disclose factors other than artificial stimuli that may conceivably affect the future market price of the registered security or for failure to discuss the likelihood of those factors assuming importance. Matter of Queensboro Gold Mines Ltd., Sec. Act Rel. I6I7 at 3 (1937). And an optimistic, estimate of future market price, if it is not impossible of realization, and if the conditions precedent to its realization are revealed, will not be held deficient in spite of proof that the party who made it believed it to be one-third too large. Matter of Ypres Cadillac Mines Ltd., Sec. Act Rel. I652 at 8 (1938). 
this general principle the commission has required the registrant, who states that the registered issue will be offered at the market, to reveal not only any devices which the registrant has used in the past, ${ }^{148}$ is presently using, or intends to use ${ }^{\mathrm{I} 49}$ in order to effect alterations in the price of its securities during their distribution, ${ }^{150}$ but, also, any marked deviation of the market for the registrant's security from the standards of a perfect market. ${ }^{15 x}$

${ }_{148}^{8}$ Matter of Rickard Ramore Gold Mines, Ltd., 2 S.E.C. 377, 384 (I937); Matter of Austin Silver Mining Co., Sec. Act Rel. 1774 at 7 (1938). The rule is seemingly applied even though counsel for the commission has offered no proof that similar devices will be employed in connection with the distribution of the registered securities.

249 Rule 505, General Rules and Regulations, Securities Act of I933, at 37 (1938); Matter of Rickard Ramore Gold Mines Ltd., 2 S.E.C. 377, 384 (I937). But of. note 147 sulpra.

rso Devices coming within the ambit of this rule include: (I) limitations on the supply of the registered security during its distribution: limitations on deliveries of securities sold, options to purchase which can be exercised only if the securities purchased are allowed to remain with the underwriter for a certain period of time, and informal agreements not to sell holdings of the registered security while it was being distributed (Matter of Rickard Ramore Gold Mines Ltd., 2 S.E.C. 377,384 ( 1937$)$ ), restrictions on the amount of registered securities which will be offered at any one time (Matter of Canusa Gold Mines Ltd., Sec. Act Rel. 1507 at 3 (1937)), and agreements to put securities of the kind registered in escrow pending the completion of distribution of the registered securities (Item 26, Form A-O-r at $\mathrm{I}_{5}$ ( $\mathrm{r}_{93} 6$ )); even the risk of limitation of supply by the issuer must be revealed (Matter of West Park Apts. Corp., Sec. Act Rel. I8II at 8 (1938) (registrant stated that it would offer securities at a minimum price of \$95.I0 on a basis of sale to the highest bidders, but failed to disclose that it reserved the right to refuse any bid in whole or part) ); (2) devices whose efficacy in manipulating or stabilizing the price of securities offered is a consequence of the ignorance of persons dealing in the stock both of its intrinsic worth and of the existence of price-fxing practices: "matched" sales, or a plan to "step-up" prices with the aid of supporting bids (Matter of Rickard Ramore Gold Mines Ltd., 2 S.E.C. 377,384 (I937)) or other stabilizing or manipulative device (Matter of Austin Silver Mining Co., Sec. Act Rel. 7774 at 7 (r938)). If the issuer or any of the underwriters has grounds to believe that stabilization is contemplated to facilitate an offering under the Securities Act, all prospectuses must indicate prominently the intent to stabilize the securities to be stabilized and the exchanges, if any, upon which the securities will be stabilized, and must inform the investor that there is no assurance that stabilization operations will be begun or continued. Rule 827, Sec. Act Rel. $189 \circ$ ( 1939 ). It has been held deficient to reveal market supporting activity by the underwriter with respect to registered shares when the registrant implies contrary to fact that the underwriter does not intend to stabilize all registered shares (Matter of Ypres Cadillac Mines Ltd., Sec. Act Rel. 1652 (I938)). The sale of a security at the market price without disclosing concurrent artificial pressure exerted on the market price by or for the seller constitutes an omission to state a material fact necessary in order to make the statement of the offering price by the seller not misleading, and is suffcient to expose the seller to liability under $\$ \mathrm{I}_{7}$ (a) of the Securities Act (Coplin v. United States, 88 F. (2d) 652, 66I (C.C.A. 9th I937), cert. denied 30I U.S. 703 (I937); Securities and Exchange Comm'n v. Otis and Co., I8 F. Supp. I00, I02 (Ohio 1936)).

15x Matter of Canusa Gold Mines Itd., Sec. Act Rel. I507 at 3 (limitation by governmental action of the number of shares in the market); Matter of Rickard Ramore Gold Mines Ltd., 2 S.E.C. 377,384 (1937) (market highly volatile due to small number of buyers and sellers). 


\section{DISCLOSURE OF UNAVOIDABLE UNCERTAINTY- DIVERSION OF FUNDS FROM THE ENTERPRISE}

Human nature being what it is, the hazard that persons who have the power to do so will divert funds from corporate purposes to achieve enrichment disproportionate to the services which they render, would appear to be a hazard as basic as is the risk that fixed assets are valued improperly. Another endeavor of the commission under the Securities Act, consequently, has been to isolate the persons with the power to divert funds from proper corporate uses, and to detect any past diversions and any diversions contemplated in connection with distribution of the registered issue. The mechanisms by which diversion can be achieved are doubtless numerous, including, for example, loans to insiders or, more rarely, loans from insiders at excessive rates of interest, sales of property to the corporation at profits which would not be realized in arms-length transactions, and sales of shares of stock to insiders at less than market price with the intent that the vendees might realize profits from resale of the stock at the market. The succeeding discussion of disclosure required with respect to stock sales by the corporation at less than market price illustrates the commission's treatment of these problems.

To understand the import of the items in the forms requiring disclosure of stock sales by the corporation at unduly favorable prices, some discussion of the mechanism of securities distribution is essential. For this purpose one may designate by the term "initial distribution" the series of transactions through which the securities pass before becoming the property of persons intending to hold as investors. Transactions by which such purchasers may later arrange the sale of their shares to the public may be referred to as "subsequent distribution."

Initial distribution may be effected either by public or private offering. When an issuer contemplates a public offering, it typically makes an "underwriting" contract with an investment banker or syndicate. By the terms of the contract the investment banker may agree to take the entire issue at a specified price per share and resell it at a higher price ${ }^{\mathrm{r} 52}$ or he may agree to purchase the unsold residue of the issue at a price less than the price at which the registrant sells the remainder. ${ }^{153}$ In either event the investment banker may receive, at the expense of the investor, a "spread" or commission larger in view of the risk assumed than would result if there were free competition between underwriters.

The commission may be larger than would be fixed by impartial market forces because it is not determined by competitive bidding, ${ }^{x 54}$ or because ${ }_{152}$ Sen. Rep. No. 1455 at 93 (73d Cong. 2 d Sess. 1934). $\quad{ }_{153}$ Id. at Iro. $\quad{ }^{254}$ Id. at 87. 
the underwriter is under no firm commitment to assume any of the risk of distribution and can therefore refuse to exercise his underwriting option unless the prospect of gain appears to him decidedly to exceed his risk of loss. ${ }^{155}$ The danger of excessive underwriting charges is, of course, substantially greater if the underwriter is in control of the issuer, or if representatives of the underwriter are members of the issuer's board of directors. ${ }^{\mathrm{x} 6}$

Two kinds of items included in the forms advise the prospective investor as to whether or not a concern in which he is solicited to invest dissipates undue proportions of money invested with it as commissions in the course of public offerings of its securities. In the first place, on the theory that practices once indulged in are likely to be repeated, the historical technique of disclosure is employed, and the registrant is required to reveal the amount and recipient of any commission paid in the course of the public offering of any of its outstanding capital stock ${ }^{157}$ or long term debt $^{\text {I58 }}$ whose primary distribution was effected within a specified period preceding registration. In the second place, the registrant under all forms must reveal commissions paid or to be paid to underwriters in connection with the initial distribution of the registered issue. ${ }^{159}$ To discover the broad significance of this second requirement implies examination of the meaning of the terms which it embodies. "Commission" is used in the very broad sense of "cash, securities, contracts, or anything else of value paid, to be set aside, or disposed of, or understandings with or for the benefit of any other person in which any underwriter is interested." 160 "Payment" includes disbursement by any affiliate of the issuer as well as payment by the issuer. ${ }^{16 \mathrm{I}}$ The term "underwriter" as defined by section

Iss Id. at $\mathrm{Ir}_{3}$. ${ }^{256} \mathrm{Id}$. at 85 .

${ }^{157}$ Instruction 16, Instructions Pertaining to Balance Sheets of the Issuer, Form A-r at 31 (r937) (information for securities issued since Jan. I, I922); Item 38, Form A-2 at ro (information for securities issued in the two years preceding registration); Instruction $2 x(b)$, Financial Statement Instruction Set No. r, Form E-I at 49 (1937) (information for securities issued in ten years preceding registration).

${ }^{25}$ Instruction $\mathrm{I} 7$, Instructions Pertaining to Balance Sheets of the Issuer, Form A-r at 3 I (1937) (information for securities issued since Jan. $x$, I922); Item 38 , Form A-2 at ro (information for securities issued in the two years preceding registration).

159 Items 24, 25, Form A-2 at 8 (I937); Item 36, Form A-I at II(I937); Item 28(c), Form E-r at $x_{4}$ (1937); Items II, I8, 20, Form A-0-I at 6, 10, II (1936). These items require the registrant to reveal the total spread between the offering price to the public and the price paid by the underwriter obtaining the securities on the best terms. Matter of Sweet's Steel Co. Sec. Act Rel. 1899 at 6 (1939).

${ }^{160}$ Instruction as to Item 24, Instructions as to Particular Items of the Form, Instruction Book for Form A-2 at 18 (1937).

16r Ibid. 
2 (II) $)^{162}$ of the Securities Act is broad enough to include many persons not ordinarily thought of as underwriters ${ }^{163}$ who receive compensation ${ }^{164}$ which is contingent upon the success of the initial distribution, ${ }^{165}$ at least, ${ }^{166}$ if their compensation exceeds the amount which would be fixed by an armslength transaction. ${ }^{167}$

${ }^{262}$ The Congressional history of this clause is given in Matter of Unity Gold Corp., Sec. Act Rel. 1776 at 8 , n. I5 (r938).

${ }^{36} 6_{3}$ One may be an underwriter whether or not he is in privity of contract with the issuer. Matter of Unity Gold Corp., Sec. Act Rel. 1776 at 9 ( 1938 ).

${ }^{164}$ It is sufficient receipt of compensation if the chief business of the claimed underwriter is the sale of its own securities and the purchase of the securities of one issuer and its affiliates. Matter of Unity Gold Corp., Sec. Act Rel. 1776 at 9 (1938).

${ }^{36}$ "Distribution, although not expressly defined in the act comprises the entire process by which in the course of a public offering, a block of securities is dispersed and ultimately comes to rest in the hands of the investing public. See Matter of Brooklyn Manhattan Transit Corp., I S.E.C. I47, I62 (1935). It is a process without finite boundaries and often includes one or more redistributions by which portions of the issue are repurchased from speculative buyers and so called weak hands with a view to replacement with permanent investors. See $\mathrm{I}_{4}$ Fletcher, Cyc. Corp. $\$$ 9212." Matter of Oklahoma-Texas Trust, Sec. Act Rel. $\times 5^{6} 3_{3}$ at 5-6, (1937), aff'd roo F.(2d) 888 (C.C.A. Ioth r939).

${ }^{166}$ This definition of underwriter is not exclusive inasmuch as the commission regards as an underwriter any person who manages the distribution of all or a substantial part of the registered issue or who performs the normal functions of an underwriting syndicate regardless of the amount of his compensation. Rule $x_{4} \mathrm{I}$ (c), General Rules and Regulations, Securities Act of 1933 at 3 (r938). The reason for this extension of definition is seemingly to force liability upon those persons who by virtue of their knowledge and influential role in determining the character of securities which are offered should be responsible.

${ }^{167}$ The proposition that one is inevitably an underwriter if the amount of his compensation depends upon the success of the distribution of the registered issue appears to follow from a number of subordinate propositions that appear explicitly in the cases.

These subordinate propositions are: (I) that one who receives compensation for services in connection with a securities distribution, the amount of which is dependent upon the success of the distribution, may be an underwriter even though he never purchased any of the registered securities. Matter of Puget Sound Distillery Inc., Sec. Act Rel. x725 (1938) (a "finder," or person who obtained an underwriter for the registrant, was held to be an underwriter when he received extra compensation for having found an underwriter); Matter of Unity Gold Corp., Sec. Act Rel. $\mathrm{r}_{776}$ at 7 ( $\mathrm{I}_{93} 8$ ) (a person who participates in the profits of an underwriting may be an underwriter even though he at no time owned any of the securities being distributed). Matter of Sweet's Steel Co., Sec. Act Rel. 1899 (r939) (in holding a party to be a principal underwriter, though he only acted as an agent in distributing shares to the public, and though he only took title to the registrant's shares as "collateral security" and as compensation for services, the commission relied strongly on the fact that the party was to be compensated with money received by distribution of the registered issue and with registered stock; it was remarked that "the nature of [the party's] interest is not compatible with that of a mere lender of money or a person performing a normal banking function. [It was] sharing the profits and risks of distribution"). See Matter of Nat'l Boston Montana Mines, 2 S.E.C. 226, 248 (I937). See also H.R. Rep. No. 85 at I3 (73d Cong. Ist. Sess. I933). (2) that one who purchases and resells the registered security in large quantities is an underwriter. H.R. Rep. No. 85 at 13 (73d. Cong. Ist Sess. I933). See Matter of Kinner Airplane and Motor Corp Itd., 
By virtue of items in the registration forms the investor is therefore afforded in every prospectus a prominent tabular summary of discounts or commissions which have been or are contemplated to be given in connection with the distribution of the registered issue, and a list of the persons who have received such amounts. Such information assumes additional significance when coupled with the required enumeration of underwriters under common control with the issuer. ${ }^{168}$

The primary distribution of securities may also involve a so-called private offering or preferred list. Under this scheme the issuer selects certain prominent persons to whom the security is offered at prices less than the price at which the security is offered to the public. The good-will of persons on the preferred list is thereby cultivated since they can resell on the market at a profit. ${ }^{169}$ The Securities Act does not require a registration statement to be effective before an issuer can legitimately make a solely private offering. ${ }^{170}$ In the event, however, that a portion of the issuer's securities is publicly offered, the registrant is required to disclose the persons or classes of persons to whom the registrant proposes to sell registered securities at prices different from the public offering price and the consideration to be received from such persons. ${ }^{17 \mathrm{I}}$ In these circumstances

Sec. Act Rel. I644 at 3 (I937) (the additional fact in that case that the underwriter was a director of the registrant is immaterial. Cf. Matter of Nat'l Boston Montana Mines, 2 S.E.C. 226, 247 (I937)). (3) that one who has a contract right to purchase and resell the registered issue on a commission basis is an underwriter (Matter of Nat'l Boston Montana Mines, 2 S.E.C. $226,247-8$ (r937) ), even though at the effective date of the registration statement he was under no firm committment to effect the distribution (Matter of Livingston Mining Co., 2 S.E.C. $x_{4} \mathrm{r}, I_{4} 8$ (I937); Instruction as to Item 22, Instructions as to Particular Items of the Form, Instruction Book for Form A-2 at 18 (r937). See also Matter of Bering Straits Tin Mines, Sec. Act Rel. ${ }_{3} 68$ at 7 (I937)).

The circumstances in which a person has been held not to be an underwriter within the meaning of the Securities Act emphasize the validity of the general proposition. Thus in Matter of South Umpqua Mining Co., Sec. Act Rel. 1694 (1938) it was held that a finder is not an underwriter because from a showing that one received a fixed fee as compensation for his efforts in seeking an underwriter it does not follow that he participated either directly or indirectly in the distribution or in the profits of the distribution. Rule $\mathrm{r}_{42}$, General Rules and Regulations, Sec. Act Rels. $186 \mathrm{r}$ and 2862 (1938) provides that one is not an underwriter who purchases a security for investment and not for commission upon resale, and who is not under common control or management with the issuer or with the principal underwriter.

${ }^{68}$ Item 28(b), Form E-I at I4 (r937); Item 22, Form A-2 at 8 (I937); Item 32, Form A-I at II (1937); Item I5(e), Form A-O-I at 9 (I936).

${ }^{69}$ Sen. Rep. op. cit. supra note I52, at Io6.

${ }_{70}$ See Securities Act of 1933 at $\S 4$ ( $($ ); Rule I52, General Rules and Regulations, Securities Act of 1933 , at 4 (1938).

${ }_{77}$ Item 35, Form A-I at II (I937); Item 26, Form A-2 at 8 (I937); for an extreme interpretation of these items see Matter of West Park Apts. Corp., Sec. Act Rel. I8Ir at 5, n. II (1938). 
the investor may determine for himself whether the corporation received consideration warranting the preferential treatment.

"Subsequent distribution" may be accompanied by some or all of the evils which were noted above in connection with primary distribution through public offerings. ${ }^{172}$ If, however, the shares are owned by a person who originally acquired them for investment and who is not in control of the issuer, it would be unduly burdensome to require registration before even a public offering; the holder would not be in a position to cause the issuer to register. Accordingly, such sales are exempted as "transactions by any other person other than the issuer, underwriter, or dealer." where the holder, by reason of affiliation with the issuer, is in a position to cause the securities to be registered, any person who sells the securities for him or buys them with a view to their resale is included within the definition of "underwriter." I74 The securities must therefore be registered and the compensation of any such "underwriter" disclosed.

The techniques available under the Securities Act are, of course, of limited effectiveness in dealing with the hazard of diversion of corporate funds through excessive underwriting fees. Such techniques are to be contrasted with that recently adopted pursuant to the Public Utility Holding Company Act. The commission's Rule U-I2F-2, adopted over the dissent of Commissioner Mathews, prohibits the payment of underwriting fees to affiliates or to "any person whom the commission finds stands in such relation to [the corporation] that there is liable to be . . . an absence of arm's-length bargaining," unless it appears to the commission that "appropriate and diligent effort was made to obtain competitive bids for the securities" or that "such effort was not practicable" and that "the remuneration is reasonable."

\section{DISCLOSURE OF AVOIDABLE UNCERTAINTIES}

A second type of uncertainty which may be present in a business enterprise may be denominated avoidable uncertainty. By avoidable uncertainty is meant any risk which confronts one investing in an enterprise and which is neither a necessary consequence of industrial organization nor a risk inherent in human nature. Such risks often result from pre-existing contracts or arrangements as to corporate structure, the effect of which cannot be determined with certainty. Two types of such sources of uncertainty are discussed below, option contracts and holding company struc-

${ }_{72}$ Notes $x_{54}, x_{55}$ and $x_{5} 6$ supra. 173 Note I7o supra.

174 H.R. Rep. No. 85 at 13 (73d Cong. Ist Sess. 1933).

${ }_{75}$ Holding Co. Act Rel. $x_{3} 80$ (I938). 
tures. It is a striking paradox that the risks which constitute avoidable obstructions to the perfect mobility of investors and to their freedom to contract arise from legal relations affecting the business enterprise, which vested as a consequence of the prior exercise by other persons of their power to contract freely.

\section{A. RISKS ARISING FROM OUTSTANDING OPTIONS}

An illustration will clarify the nature of the type of uncertainty arising from option contracts to which the registrant is a party. Suppose that a corporation has issued $I, 000$ shares of preferred stock with a par value of \$1o each, that on liquidation of the corporation holders of preferred shares are entitled to preference of $\$ 120$ per share, and that holders have the option at any time to exchange each share of preferred for five shares of common. Under these circumstances how should the liquidation and conversion rights be set forth and how is the effect of these provisions to be evaluated, for example, by a prospective purchaser of an additional issue of common stock? It is obvious that the balance sheet technique is of little help in this connection. A liquidation preference which exceeds the consideration received for preferred shares can usually be shown only parenthetically, and the significance of the item is almost entirely speculative since the likelihood of liquidation, voluntary or involuntary, can seldom be estimated.

In view of these and other contingencies arising out of investment contracts, the commission requires that the issuer reveal not only the par or stated value of stock and the maturity value of long term obligations which the registrant has issued or is issuing under the registration statement, but also the rights and liabilities evidenced under different contingencies by all of the registrant's securities outstanding or to be offered under the registration statement, ${ }^{x 76}$ and the number and nature of all such

${ }_{17}$ Capital Stock: Item 16, Form A-I at 3 (I937); Item 53, Form A-I at I9 (I937); Item 53, Form A-O-I at 31 (1936); Item 54, Form A-O-I at 32 (I936); Items x6, I7, I9, Form A-2 at 7 (I937); Item II(a)(b), Form E-I at 9 (I937); Item I3, Form E-I at Io (I937). Accounting Rel. 9 (1938) states that in the opinion of the Commission's chief accountant the preferences on involuntary liquidation in excess of the par or stated value of preferred or any other senior class of stock should be disclosed, preferably in the balance sheet, and that when the excess is significant, there should be shown in the balance sheet or in the footnotes thereto the difference between the aggregate preference on involuntary liquidation and the aggregate par or stated value, and a statement as to any restrictions on surplus arising from this fact; in the event that the total of liquidation preference and dividend arrears of any senior class of stock exceeds the sum of the par or stated value of the junior capital and of surplus, the registrant must also disclose this fact in the balance sheet or by footnote to the balance sheet. Form A-2 requires balance sheets to disclose arrears in cumulative dividends, Note $B$, Instruction Book for Form A-2 at 35 (I937). In Matter of Lewis American Airways Inc., I S.E.C. $33^{\circ}, 343$ (I936) it was 
securities which the registrant is authorized to issue subsequent to completion of the distribution of the registered issue. ${ }^{\mathrm{x} 77}$ The registrant must also disclose any provisions for funds necessary to meet liabilities to existing investors ${ }^{178}$ and any default in making additions to such funds under such provisions. ${ }^{\text {I79 }}$

The option contract is thus an important source of avoidable risk. The registrant may grant options which are embodied in the securities it sells, ${ }^{x 80}$ or it may grant options to purchase securities. ${ }^{\text {xI }}$ The strict standards of disclosing the consequences of these options which the commission may uphold are suggested by the disclosure which the commission deems essential when the registrant is the owner, at the effective date of the registration statement, of a lease and option to purchase a mining claim. Such a registrant is required to disclose in a footnote to the balance sheet or elsewhere any assets that it would lose if remaining payments under the lease and option agreement were not made. ${ }^{82}$ In addition, the registrant may not set up balance sheet entries which would indicate that the fee in the property held under lease and option had passed to the registrant, with the remainder due under the option treated as a simple

held that the registrant must divulge any charter provisions forbidding cumulating voting. Funded Debt: Items I4, I5, Form A-2 at 6 (1937); Items II, I2, I3, I4, Form E-I at 9-10 (I937); Item 23, Form A-I at 7 (I937); Item 54, Form A-O-I at 32 (I936). Other Securities: Items I8, I9, Form A-2 at 7 (I937); Items I2, I3, Form E-I at Io (I937); Item 54 Form A-O-I at 32 (1936).

${ }_{77}$ Capital Stock: Instruction I6A, Instructions Pertaining to Balance Sheets of the Issuer, Form A-I at 3I (I937); Item 20, Form A-I at 5 (I937); Item 52, Form A-O-r at 30 (I936); Schedule V, Instruction Book for Form A-O-I at ro (I936); Instruction 21, Financial Statement Instruction Set No. I, Form E-I at 49 (I937); Item 9, Form E-I at 7 (I937); Items Io, 13, Form E-r at 8, ro (r937). Funded Debt: Item 9, cols. A to D, Form A-2 at 2 (I937); Schedule $X$, cols. A to E, Instruction Book for Form A-2 at 49 (I937); Schedule XI, cols. A to E, Instruction Book for Form A-2 at 50 (1937); Item 2I, Form A-I at 6 (I937); Item 22, Form A-I at 7 (1937); Items Io, 13, Form E-I at 8, Io (x937); Item 52, Form A-O-I at 30 (1936). Other Securities: Item ro(b), Form E-I at 8 (I937); Items II, I2, I3, Form A-2 at 4, 5, 6 (1937); Item 52, Form A-O-I at 30 (I937).

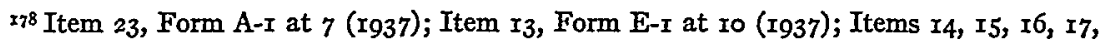
Form A-2 at 6-7 (I937); Items 53, 54, Form A-O-I at 3I, 32 (r936).

179 Note $C$, Instruction Book for Form $A-2$ at 35 (1937). This data must be furnished whether or not specifically required by the form. Matter of Oklahoma Hotel Bldg. Corp., Sec. Act Rel. rgoo (I939).

${ }^{280}$ Note 176 supra.

${ }^{188}$ Item 56, Form A-O-x at 32 (1936); Item 39, Form A-2 at ro (I937). Item 38, Form E-I at 16 (1937); Item 25, Form A-r at 7 (I937).

${ }^{182}$ Matter of.Canusa Gold Mines Itd., Sec. Act Rel. ${ }^{507}$ at 7 (1937). Cf. Schedule IV, 2, Instruction Book for Form A-O-r at 9-10 (I936). 
debt. $^{.83}$ Since the registrant which holds an option has the legal power to determine the consequences of the option contract, these results can only be justified on the ground that that unavoidable economic uncertainty which faces every registrant may be displaced by the certainty of inadequate quick assets. ${ }^{184}$ If the rule of these cases is that, when the registrant is a party to an option contract, it must disclose the potential consequences of the contract most unfavorable to the registrant, it certainly should be applied $a$ fortiori when the party with whom the registrant has contracted is the optionee with legal power to determine the consequences of the contract. ${ }^{185}$

\section{B. RISKS ARISING FROM HOLDING COMPANY STRUCTURES}

The second species of avoidable uncertainty, which the commission requires the registrant to reveal, consists of uncertainties arising from the structure of corporate enterprise. Assume for example that the registrant is a holding company with two subsidiaries and that a majority of the voting stock in the holding company is owned by another holding company which has four subsidiaries aside from the registrant and its subsidiaries. Assume further that the controlling interests in the top holding company in the system are honestly concerned entirely with the advancement of the business interests represented by the top holding company and its seven subsidiaries. To advance the business interests of the entire system it may be to the interest of the top holding company to divert funds from the registrant and/or its subsidiary regardless of, or even contrary to, the best interests of the business enterprise composed of the

${ }^{283}$ Matter of Franco Mining Co., I S.E.C. 285, 289 (r936); Matter of American Terminals and Transit Co., I S.E.C. 70r, 707-708 (1936); Matter of Canusa Gold Mines Ltd., Sec. Act Rel. $x_{507}$ at 7 (I937). See Matter of Paper Sales Co. of Detroit, Sec. Act Rel. 1556 (r937) as amended by Sec. Act Rel. I665 (I938).

${ }^{184}$ The reader may perceive the suggestion of a principle of conservatism traceable in the rule which has just been discussed, the rule as to the measure of cost of fixed assets (p. 4II supra), and the rule that income may not be taken until realized (p. 420 supra). If the commission does consistently follow the principle of conservatism which is said in Graham and Katz, op. cit. supra note 54 at $\$ 103$ (Ist ed. I932) to be one of the root principles of orthodox accounting practice, it would appear to have unconsciously encroached upon its important basic principles of requiring disclosure of known facts and of areas of doubt. The effect of the principle of conservatism is to mislead investors e.g., in the situation where two concerns have substantially the same financial prospects assuming that all contingencies reasonably to be anticipated as affecting the concerns turn out most unfavorably, and where their financial prospects are vastly different assuming contingencies anticipated as affecting the concerns turn out favorably.

${ }^{\text {r85 }}$ Cf. Matter of Bankers Union Life Co., 2 S.E.C. 63 , 68 (I937) with Matter of Haddam Distillers Corp., I S.E.C. 48, 52 (I934), and with Matter of Bering Straits Tin Mines Inc., Sec. Act Rel. 1498 at 9 (I937). 
registrant and its subsidiaries. The inevitable consequence is that the investor in the registrant is exposed to a risk of diversion of funds from the system including the registrant and its subsidiaries on whose financial welfare the welfare of the investor entirely depends, a risk which arises from the fact that the business interests of that system may be in conflict with those of the larger system of which it is a part. ${ }^{\mathbf{x 6}}$ This risk is therefore inherent when investment is made in a subsidiary of a holding company, and may be abolished only by either abolishing holding companies or by preventing holding company subsidiaries from selling securities.

The commission, of course, has no power to require either of these courses of action under the Securities Act of I933. In carrying out its policy of requiring the disclosure of data in a mode without tendency to misinform, ${ }^{x 87}$ it must confine itself to enabling the investor to pierce the artificialities of corporate form to understand the enterprise in which he is asked to invest. So the commission can and does insist on the one hand that the registrant must disclose all corporations which are under common control with the registrant, and any available data with respect to transactions by virtue of which any such corporation has siphoned funds to ${ }^{\text {I88 }}$ or away ${ }^{189}$ from the system which includes the registrant and its subsidiaries; and on the other hand that there be full disclosure with respect to the business condition of the registrant and its subsidiaries, since it is in the success of this system that the investor has a legal interest.

${ }^{186}$ Whenever one person serves two masters whose interests are conflicting, each master faces the risk that his servant will not serve his interests. The commission requires disclosure of conflicting interests of persons who control or benefit from disposition of corporate funds. See $e . g$., note 168 supra. Conflicts of interest can only be dealt with effectively by prohibiting persons from assuming incompatible functions. See 49 Stat. 89 I (r934), I5 U.S.C.A. $\$ 78 \mathrm{k}$ (Supp. I938); Meck and Cary, Regulation of Corporate Finance and Management under the Public Utility Holding Company Act of 1935,52 Harv. L. Rev. $2 x 6$ (I938).

${ }^{287}$ Pp. 402-7 supra.

${ }^{188}$ This might conceivably be done as part of a scheme to improve the registrant's apparent business condition in order to stimulate its sales of stock during the period of securities distribution. Cf. Sen. Rep. No. 1455 at 382 (73d Cong. 2d Sess. 1934): "The primary motivation of the organization of the holding company has now become the development and financial promotion of security selling schemes. The holding company per se has become the most important unit, and the industry or operating companies merely tools or instrumentalities of financial promotion and security speculation."

${ }^{289}$ The prejudicial effect on the investor in a subsidiary of a so-called "upstream" diversion to a parent of the subsidiary is obvious. But a downstream loan may also be prejudicial. Suppose for example that the $A$ holding company owns $5 \mathrm{I} \%$ of the one class of stock of the $\mathrm{B}$ company and $49 \%$ of the one class of stock of the C company, that the B company owns $5 \times \%$ of the stock of the $C$ company, and that the $A$ company uses its voting power in the $B$ company to shift $\$$ roo, $\infty 00$ from the $B$ company to the $C$ company. The effect of this transaction will be to increase the equity of the $A$ company in the $\$ 100,000$ from $\$ 5 I, 000$ to $\$ 77,010$ and to decrease the equity of minority stockholders in the B company by $\$ 26,0$ ro. 
The commission requires disclosure of intercompany transactions within an enterprise composed of the registrant corporation and of all its affiliates. The registrant consequently must segregate and reveal current $^{\mathrm{x} 90}$ or long term ${ }^{\mathrm{rgx}}$ loans made by $\mathrm{it}^{\mathrm{xg2}}$ or by one of its subsidiaries ${ }^{\mathrm{x} 93}$ to parents of the registrant or to persons under common control with the registrant, as well as loans made by the registrant to any of its subsidiaries. ${ }^{194}$ Conversely, the registrant is required to segregate and disclose current $^{\mathrm{x} 95}$ and long term ${ }^{\mathrm{x} 96}$ loans by affiliates to the registrant ${ }^{\mathrm{T} 97}$ and to its subsidiaries. ${ }^{x 98}$

One method by which funds may be diverted away from or to the system composed of the registrant and its subsidiaries is by sale of property to the registrant ${ }^{199}$ or to a subsidiary ${ }^{200}$ at other than the going market rates. If any affiliate acquired property not more than two years before the resale to the registrant or to one of its subsidiaries, all forms require that the registrant reveal the cost of the property to the affiliate. ${ }^{201}$ Some forms

${ }^{290}$ Instruction 24 for Balance Sheets of the Issuer, Instruction Book for Form A-2 at 34 (1937); Instruction I7, Financial Statement Instruction Set No. I, Form E-I at 48 (1937); Instruction 20, Instructions Relative to Balance Sheets of the Issuer, Form A-r at 32 (r937).

${ }_{99 x}$ Schedules X, XI, Instruction Book for Form A-2 at 49, 50 (I937) (applies only to funded debt).

${ }_{292}$ Item 54, Form A-I at 20 (I937); Item 49, Form E-I at I9 (I937); Exhibits P, R and S, Form E-r at 22 (1937); Special Rules $5 \mathrm{~B}_{2}(\mathrm{a}),{ }_{5} \mathrm{~B}_{3}(\mathrm{a})$ and of. ${ }_{5} \mathrm{Br}(\mathrm{a})$, Instruction Book for Form A-2 at 6, 8, 9 (I937); Instruction I, Instructions as to Financial Statements Instruction Book for Form A-2 at 22 (1937).

${ }_{93}$ Item 50, Form E-I at 19 (1937); Exhibit V, Form E-I at 23 (1937); Special Rules $5 \mathrm{BI}$ (c), ${ }_{5} \mathrm{~B}_{2}$ (d) and ${ }_{5} \mathrm{~B}_{3}(\mathrm{c})$, Instruction Book for Form $\mathrm{A}-2$ at $7,8,9$, ( I937); Instruction $\mathrm{r}$, Instructions as to Financial Statements Instruction Book for Form A-2 at 22 (1937).

r94 Instruction 24, Instructions as to Balance Sheets, Instruction Book for Form A-2 at 34 (1937); Instruction $\mathrm{r}$, Financial Statement Instruction Set No. I, Form E-I at 48 (I937); Instruction 20, Instructions Pertaining to Balance Sheets of the Issuer, Form A-I at 32 (1937); Schedules X, XI, Instruction Book for Form A-2 at 49, 50 (r937) (applies only to funded debt).

295 Instruction 24, Instructions as to Balance Sheets, Instruction Book for Form A-2 at 34 (I937); Instruction ${ }_{3}$, Instructions Pertaining to Balance Sheets of the Issuer, Form A-r at 3r (I937); Instruction r7, Financial Statement Instruction Set No. r, Form E-r at 48 (I937).

${ }^{196}$ Instruction 27, Instructions as to Balance Sheets, Instruction Book for Form A-2 at 34 (I937); Instruction I8, Instructions Pertaining to Balance Sheets of the Issuer, Form A-I at 3I (1937); Instruction 19, Financial Statement Instruction Set No. r, Form E-r at 48 (I937). 297 Note 192 supra. ${ }^{198}$ Note $\mathrm{x} 93$ supra.

${ }_{299}$ Items 26 and 27 , Form E-I at $I_{3}, I_{4}$ (I937); Special Rules ${ }_{5} \mathrm{~B}_{2}$ (a), $5_{5} \mathrm{~B}_{3}$ (a) and $c f .{ }_{5} \mathrm{BI}$ (a), Instruction Book for Form A-2 at 6,8,9 (I937); Instruction I, Instructions as to Financial Statements Instruction Book for Form A-2 at 22-3 (r937).

${ }^{200}$ Note I93 supra.

${ }^{201}$ Items 26(a)(6), 26(b)(4), and 27, Form E-I at I3, I4 (I937); Schedule II, note 3, and Schedule IV; note 2, Instruction Book for Form A-2 at 4I, 43 (I937). 
have more stringent provisions to insure disclosure of profits or losses to affiliates of the registrant on such sales of property..$^{202}$

A third way in which the commission throws light on diversion of funds to or from the registrant is by requiring the disclosure of commissions paid to affliates of the registrant on the sale of long term obligations ${ }^{203}$ or capital stock ${ }^{204}$ of the registrant ${ }^{205}$ or of its subsidiaries. ${ }^{206}$

If the investor is to have any basis of comparing the registrant's rate of profit with the rate of profit of other concerns, the registrant must publish an accurate statement of income. The registrant is consequently called upon to segregate gross sales to affiliates ${ }^{207}$ and dividends from affiliates ${ }^{208}$ from income which was received at arms-length, and which was therefore assuredly legitimate income, and not the product of a bookkeeping device.

Since the investor is interested financially only in the enterprise composed of the registrant and its subsidiaries, the registrant must include in the registration statement balance sheets of the registrant and of its subsidiaries and in general need include no others, ${ }^{209}$ and must describe the plants and equipment ${ }^{2 \pi 0}$ and any material franchises and concessions ${ }^{2 x x}$ owned by its subsidiaries, and the business of its subsidiaries ${ }^{222}$ insofar as they are "materially important to the total enterprise represented by the registrant and its subsidiaries."

${ }_{202}$ Instruction xo(b), Financial Statement Instruction Set No. I, Form E-I at 46 (I937); Instruction 6B, Instructions Pertaining to Balance Sheets of the Issuer, Form A-I at $3 \circ$ (I937); Item 44, Form A-I at I 5 (I937).

${ }^{203}$ Instruction $\mathrm{I} 7$, Instructions Pertaining to Balance Sheets of the Issuer, Form A-I at 3 (I937).

${ }^{204}$ Instruction I6, Instructions Pertaining to Balance Sheets of the Issuer, Form A-I at 3I (1937).

${ }^{205}$ Note 192 supra. ${ }^{206}$ Note 193 supra.

${ }^{207}$ Instruction I, Instructions Relative to Profit and Loss Statements, Form A-I at 33 (1937); Instruction I, Financial Statement Instruction Set No. 2, Form E-I at 5 I (1937); Instruction IA, Instructions Relative to Profit and Loss Statements, Instruction Book for Form A-2 at 36 (I937).

${ }^{208}$ Schedule IX, Instruction Book for Form A-2 at 48 (I937); Instruction 5, Instructions Relative to Profit and Loss Statement, Form A-I at 33 (r937); Instruction 5, Financial Statement Instruction Set No. 2, Form E-I at $5^{\text {I }}$ (x937).

${ }^{209}$ Instruction I, Instructions as to Financial Statements, Instruction Book for Form A-2 at 22 (I937); Item 50, Form E-I at I9 (I937); Item 56, Form A-I at 28 (1937).

${ }^{200}$ Instruction as to Item 7, Instructions as to the Particular Items of the Form, Instruction Book for Form A-2 at 16 ( I937). $_{93}$.

axx Instruction as to Item 8, Instructions as to the Particular Items of the Form, Instruction Book for Form A-2 at I6 (1937).

${ }_{22}$ Instructions as to Items 5 and 6, Instructions as to the Particular Items of the Form, Instruction Book for Form A-2 at I6 (r937). 
The modes in which the forms qualify the general conception that the enterprise, in the financial success of which the investor is interested, includes the registrant and its subsidiaries tend more to emphasize than to restrict the general validity of the conception of the enterprise as including the registrant and its subsidiaries. ${ }^{213}$ Apparent exceptions in favor of requiring financial statements in circumstances in which the registrant does not have control of the corporation whose financial status is sought to be revealed all relate to corporations whose securities or assets are to be acquired and arise from the commission's recognition ${ }^{254}$ of the importance of the investor's having a picture of the financial conditions after the sale of the registered issue has been effected and its proceeds used as proposed..$^{215}$

The forms are not uniform as to whether or not the concept of the enterprise as including the registrant and its subsidiaries should include only those subsidiaries in which the registrant has impregnable ${ }^{216}$ control by virtue of ownership of $50 \%$ or more of the voting stock, ${ }^{217}$ or whether the concept of the enterprise should include the registrant and any other corporations which it actually controls. ${ }^{2 \times 8}$

Within the limits of the enterprise composed of the registrant and its subsidiaries, there remains the problem of presenting the financial condition of the group in such manner as to emphasize diversities as well as unities within the system. There is, of course, no reason for supposing that every system of a registrant and subsidiaries approximates a maximum of productive efficiency. The system may have been "too big too long";219 it may include unprofitable or less profitable elements that should be eliminated or again it may not be functionally integrated for

${ }_{2 \times 3}$ Instruction $x(c)$, Instructions as to Financial Statements, Instruction Book for Form A-2 at 22 (1937). Cf. Instruction as to Item 4(a), Instructions as to Particular Items of the Form, Instruction Book for Form A-2 at $\mathrm{I}_{4}$ (1937); Instruction 8, Instructions as to Preparing Form E-r, Instruction Book for Form E-I at 5 (I937). Instruction 4(I)(3), Instructions as to Financial Statements, Instructions for Form A-2 at 26 (I937).

${ }_{274}$ Pp. 422-24 supra.

${ }^{215}$ Instruction $2 \mathrm{~b}(\mathrm{ii})$, Instructions as to Financial Statements, Instruction Book for Form A-2 at 24 (r937); Item 46, Form E-r at 18 (1937).

${ }^{276}$ Except as affected by events of default.

${ }_{27}$ Item 50, Form E-I at I9 (I937); Exhibit V, Form E-I at 23 (I937). Instruction I(a)(b)(c), Instructions as to Financial Statements, Instruction Book for Form A-2 at 22 (r937); Instruction 3 (b), Instruction Book for Form A-2 at 24 (1937). Even under these forms, however, the registrant is required to disclose the structure of the registrant and all its subsidiaries. Item 24, Form E-x at I2 (1937); Item 4(a), Instruction Book for Form A-2 at $x_{4}$ (1937).

${ }_{218}$ Item 56, Form A-r at 28 (I937).

2x9 See 17 Fortune No. 3 at 69 ( 1938$)$; I 7 Fortune No. 4 at 63 ( ${ }_{993} 8$ ). 
productive purposes. ${ }^{20}$ The commission has adopted few rules with respect to the proper mode of presenting the relationship of the parts of the "enterprise" to the whole. Of most general significance are the views that the purpose of the consolidated balance sheet is to reflect the financial condition of a parent company and its subsidiaries as if they were a single organization, ${ }^{22 x}$ and that consequently the registrant must follow that principle of inclusion or exclusion in consolidating statements of subsidiaries with its own statements, which in the opinion of its officers will most clearly exhibit the financial condition and results of operations. ${ }^{222} \mathrm{~A}$ few more definite requirements, however, have been imposed. Although the forms are not uniform as to whether or not the registrant must file reports of subsidiaries that it controls with less than $50 \%$ ownership of stock, no statement of a subsidiary may be consolidated with a statement of the registrant unless the registrant has unshakable control ${ }^{223}$ over the subsidiary because of its possession of over $50 \%$ of the voting power in the subsidiary. ${ }^{224}$ If, by virtue of this rule or of the general rule as to consolidation, the registrant may not consolidate the statement of a subsidiary with its own, it must segregate and disclose any earnings of the unconsolidated subsidiaries accrued on the books of the registrant but not realized by the registrant. ${ }^{225} \mathrm{~A}$ balance sheet consolidating the accounts of the registrant and of one or more of its subsidiaries must substitute the parent's actual equities in the subsidiaries' net assets for its

${ }^{220}$ Cf. 49 Stat. 820 (1935), I5 U.S.C.A. \$ $79 k$ (Supp. 1938).

${ }^{22 x}$ Accounting Rel. 3 ( ${ }_{93} 8$ ).

222 Instruction I, Financial Statement Instruction Set No. 3, Form E-I at 52 (1937); Instruction 3 (b), Instructions as to Financial Statements, Instruction Book for Form A-2 at 24 (I937). But Form A-I merely requires the issuer to state the guiding principle followed in consolidating accounts. Item 56, Form A-I at 28 (1937). The principles of consolidation followed by the registrant must be stated. Accounting Rel. 7 at 3 (r938).

223 Note 215 supra.

${ }^{224}$ Instruction $3(\mathrm{~b})$, Instructions as to Financial Statements, Instruction Book for Form A-2 at 24 (I937); Item 50, Form E-r at 19 (1937). But there is no such requirement in Form A-I (I937).

${ }^{225}$ Instruction 6(a), Financial Statement Instruction Set No. r, Form E-I at 45 (1937); Instruction 24, Financial Statement Instruction Set No. r, Form E-r at 49 (r937). But Forms A-r and A-2 require this separate statement only with respect to income reflected in the profit and loss statements of the issuer in the period for which profit and loss statements are furnished. Instruction 25, Instructions Relative to Profit and Loss Statements, Form A-I at $3^{2}$ (1937); Instruction 3(b), Instructions as to Financial Statements, Instruction Book for Form A-2 at 25 (1937). Form A-2, however, requires the registrant to reveal in the consolidated balance sheet the extent to which the equity of the registrant in any of its unconsolidated subsidiaries has been increased or decreased since the date of acquisition of such subsidiary. Instruction $3(\mathrm{~b})$, Instructions as to Financial Statements, Instruction Book for Form A-2 at 25 (I937). 
investments in subsidiaries ${ }^{226}$ and must state separately minority interest in the capital and surplus of subsidiaries consolidated. ${ }^{227}$ In addition, intercompany profit and losses must be eliminated in the consolidated profit and loss statement insofar as is possible..$^{228}$

The prior discussion has been of the static concept of the enterprise developed by the Securities and Exchange Commission. As an outgrowth of this static concept, the commission is apparently developing a temporal concept of the enterprise which differentiates the length of time spanning the incorporation and dissolution of the registrant corporation from the period of existence of the business enterprise.

In the first place if the registrant was organized to take over a preexisting business and if the organization which carried on that business was under common control with the registrant, the commission appears to require the same disclosure with respect to the registrant's predecessor as with respect to the registrant. Thus, in the recent case of Matter of Breeze Corporation, ${ }^{229}$ one $\mathrm{M}$ controlled company $\mathrm{C}$ which sold its assets including patents to company $B$, also controlled by $M$, in return for stock of company B. At or about the time of this sale, the patents sold were written up in accordance with an appraisal by $\mathrm{L}$. The evidence was inconclusive as to whether $\mathrm{L}$ was acting for company $\mathrm{C}$ before the sale or for company $B$ after the sale. I was a patent lawyer and an engineer, but he neither was nor held himself out to be an accountant. $\mathrm{L}$ knew nothing of company B's manufacturing costs or financial condition and made no independent investigation or special study of the value of the patents. He calculated the value of the patents by assuming a certain sales volume for to years, and by calculating an "actual value of the patents on a royalty basis" at a certain percentage of such sales. This "actual value" exceeded the cost of the patents to company C. During the ensuing ten years, the sales volume never reached that which $L$ had assumed, but the balance sheet of company B nevertheless continued to show the patents at the values assigned to them by $\mathrm{L}$. Such value was described as "cost based on book value assigned by B's predecessor." As grounds for their

${ }_{226}$ Accounting Rel. 3 (I937).

${ }^{227}$ Accounting Rel. 7 at 3 (1938); Instruction 3 (b), Instructions as to Financial Statements, Instruction Book for Form A-2 at 24 (1937); Instruction 2, Financial Statement Instruction Set No. 3, Form E-I at 52 (1937).

${ }_{228}$ Accounting Rel. No. 7 at 3 ( 1938 ); Instruction 3 (b), Instructions as to Financial Statements, Instruction Book for Form A-2 at 25 (r937); Instruction 3, Financial Statement Instruction Set No. 3, Form E-I at 52 (1937); but Form A-I merely requires the registrant to furnish a statement showing all eliminations of intercompany items.

229 Sec. Act Rel. 1786 at I4 (I938). 
decision that it was materially misleading for the registrant to fail to disclose the write-up by $I$ and the circumstances casting doubt upon its soundness, the commissioners made a finding that the business of company B was a "continuation" of that of company C, and argued that the significant thing to the investor was the cost of the assets to the enterprise as distinguished from their cost to the corporation registering.

The principle of this case may be that, if a first corporation succeeds to any fixed asset theretofore owned by a second corporation under common control with the first corporation, the first corporation can place no balance sheet valuation upon the fixed asset which the second corporation could not have placed upon the asset. Or the rule conceivably is that when one corporation under common control with another corporation acquires a fixed asset of the latter, the former corporation must disclose the cost of the asset to itself and the cost of the asset to its predecessor. Either principle is consistent with the concept that the life of the enterprise is co-extensive with the time span of the functional business in which the registrant is engaged for such time as that business has been under a single control. Either principle is inconsistent with any identification of the life of the enterprise with the corporate life of the registrant.

What slight evidence appears from the forms confirms the conclusion that the commission is interested in transactions during the past life of the same functional business under the same control rather than in transactions during the past life of the corporation endeavoring to register. The registrant which employs Form A-2, for example, must furnish the historical financial information required by item $45^{230}$ not only as to its own balance sheet accounts, but also must where practicable give a historical analysis of the accounts of any corporation which was under substantially the same control as the registrant at a time when the registrant succeeded to all or a substantial portion of the corporation's assets. ${ }^{23}$ Form A-O-I goes even further inasmuch as thirteen items in the form must be answered with respect to any corporation which the registrant was organized to take over, whether or not the corporation whose business was assumed was under common control with the issuer at the date of transfer. ${ }^{232}$

${ }^{230}$ Form A-2 at II (1937).

${ }^{23 x}$ Instructions as to Item 45 , Instructions as to Particular Items of the Form, Instruction Book for Form A-2 at 2I (I937).

${ }_{232}^{2}$ Instructions as to Items 3 to $\mathrm{I}_{4}$ inclusive, Instruction Book for Form A-O-I at 2 (r936). But $c f$. Rule as to use of Form A-O-I, Instruction Book for Form A-O-r at r (r936). Cf. Rules 2, 3, 4, Special Rules as to the Use of Form A-2 for Corporations, Instruction Book for Form A-2 at 2-IO (I937). 
On the other hand, that one form does not require historical financial data is not essential with respect to a period in the history of the registrant corporation at a time when its business and possibly its management and control ${ }^{233}$ were substantially different at the date of registration..$^{234}$

\section{SUMMARY-AVOIDABLE UNCERTAINTY}

The foregoing survey of the experience of the commission suggests that even the most elaborate disclosure will fail to enable investors to understand the structures of enterprise in which they are solicited to invest. It may be that, unless some limits are placed upon the complexity of corporate structures and the types of securities which may be sold, the hope may be largely illusory that competition for investment funds can operate in substantial measure to direct the flow of capital into enterprises which are most productive.

Even if it were assumed that investors can and do understand the structures of business enterprises in spite of their legal complexities, the fact remains that if a business grants options to outsiders, or if a holding company subsidiary issues securities, risks are introduced into the structure of the enterprise which no disclosure can dispel. Only legislation which prohibits the issuance of conversion rights to preferred stockholders can ward off the risk which common stockholders may face through dilution of voting power or less frequently through dilution of equity. Similarly only regulatory measures abolishing the issuance of securities by subsidiaries can remove the risk that a top holding company acting in the financial interest of the holding company and of all its subsidiaries, will divert funds from a subsidiary upon whose economic welfare some investors are entirely dependent.

\section{CONCLUSION}

If economic theory stemming from Adam Smith, that is an analysis of the operation of a competitive, free enterprise system of organization, is thought to furnish a blueprint of the good society, social engineering is necessary to promote conformity to the blueprint. One important reason for the divergence between actual conditions and those visualized by proponents of such theory is the lack of mobility of persons performing functions in existing economic societies. The central policy of the Securities Act is to encroach upon the lack of mobility of capital by securing the full

${ }^{233}$ Financial Statements prior to Discharge in Bankruptcy, Form A-r at 28A (1937).

234 Financial Statements in the Event of Change in Stock Ownership, Property and Business, Form A-r at 28A (r937). 
information of persons supplying funds to business enterprises. Full information not only implies information as to all matters that may reasonably be known with reference to any business enterprise seeking new funds; its other facet is the full disclosure of risks inherent in the enterprise seeking funds.

The discussion traced the Securities and Exchange Commission's use of the techniques of standardized money valuation, abandonment of money valuation, historical financial, and supplementary information as media of disclosure of risks. The attempt was made to differentiate between those risks which are unavoidable and those risks which are avoidable to bring into sharp focus the contrast between human inability to handle problems of imperfect mobility arising from unavoidable risk by any technique other than as-perfect-as-possible disclosure, and the inability of the technique of disclosure to eliminate those uncertainties which are avoidable. The problem of valuing fixed assets presents the extreme situation in which the best that can be done is to bring all techniques of disclosure to bear upon the problem of valuing uncertainty. Evaluation of risks arising from arrangements made prior to the date at which the investor is solicited to invest presents the other extreme situation in which disclosure can only make persons aware of the risk whereas other forms of regulation might remove the risk. The risk of diversion of funds from the enterprise presents in some sense an intermediate problem. Presumably disclosure will to some extent deter persons from engaging in such diversion. As to many types of diversion, however, other sanctions may be necessary to supplement the general rules of the common law governing the legal position of business fiduciaries. ${ }^{235}$

${ }_{235} C f . \S \mathrm{r} 6$ of the Securities Exchange Act and $\S \S \mathrm{I}_{2}$ and $\mathrm{r}_{3}$ of Title $\mathrm{I}$ of the Holding Company Act. 